\title{
TOO LARGE OR TOO SMALL? RETURNS TO SCALE IN A RETAIL NETWORK
}

\author{
František Brázdik \\ Viliam Druska
}
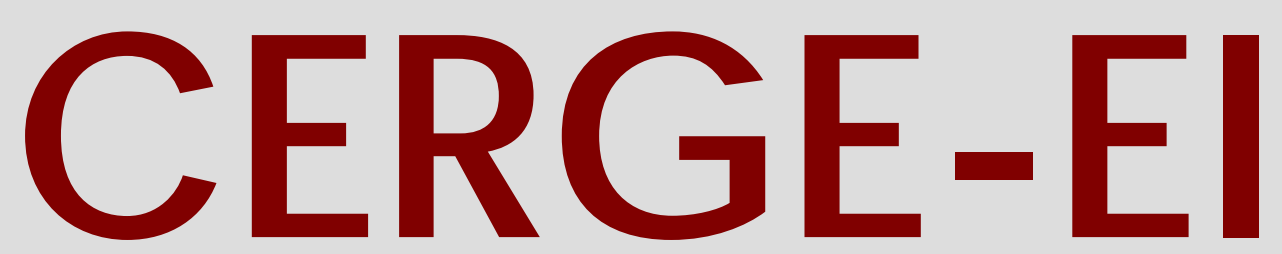

Charles University CenterforEconomic Research and Graduate Education Academy of Sciences of the Czech Republic Ec onomic s Institute 


\section{Working Paper Series 273 (ISSN 1211-3298)}

\section{Too Large or Too Small? Returns to Scale in a Retail Network}

František Brázdik

Viliam Druska

CERGE-EI

Prague, September 2005 
ISBN 80-7343-065-7 (Univerzita Karlova v Praze, CERGE)

ISBN 80-7344-054-7 (Národohospodářský ústav AV ČR, Praha) 


\title{
Too large or too small? Returns to scale in a retail network
}

\author{
František Brázdik* Viliam Druska \\ CERGE-EI
}

September 2005

\begin{abstract}
Performance in retailing is usually evaluated by routine use of ratio analysis, but due to the univariate nature of this simple management tool there are many drawbacks to the obtained results. Therefore, the aim of this study is to demonstrate successful employment of parametric and non-parametric methods for evaluating technical performance in retailing. We also show how to utilize DEA results, when parametric methods do not satisfactorily perform due to their strict distributional assumptions. Results of this study are used to optimize the retail chain of a European mobile telecommunication network operator by providing estimates of and recommendations for improvements in the productive efficiency of the chain operations. Estimates of store-level technical and scale efficiency indicate that a majority of stores are operating in the decreasing returns to scale region of the production possibility set. The employed methodology allows us to identify input excesses and to address a means of reducing them.
\end{abstract}

\begin{abstract}
Abstrakt
Technická efektivnost je obvykle hodnocena pomocí analýzy vstupněvýstupních poměrů, avšak tento přístup selhává v př́ípade produčkního procesu s více vstupy a výstupy. Proto je cílem této studie demonstrovat použití parametrických a neparametrických př́stupů k odhadu technické efektivnosti. V této studii ukazujeme využití výsledků neparametrického přístupu v případě selhání parametrické metody v důsledku jejích striktních předpokladů. Výsledky této studie byly použity při optimalizaci prodejní sítě operátora mobilní telefonní sítě. Odhady technické efektivnosti a efektivnosti rozsahu operací indikují, že vetšina obchodů se nachází v oblasti klesajících výnosů z rozsahu. Použitá metodologie umožňuje identifikaci neefektivního využití vstupů při hledání možností pro zvýšení efektivity.
\end{abstract}

Keywords: data envelopment analysis application, linear programming, efficiency, retail units

JEL classification: C14, C44, D24, L81

*Email: frantisek.brazdik@cerge-ei.cz

${ }^{\dagger}$ A joint workplace of the Center for Economic Research and Graduate Education, Charles University, Prague, and the Economics Institute of the Academy of Sciences of the Czech Republic. Address: CERGE-EI, P.O. Box 882, Politických vězňů 7, Prague 1, 111 21, Czech Republic 


\section{Introduction}

Even while increasing market penetration may set a limit on the future revenue growth of mobile network operators, high earnings expectations can still persist on the side of shareholders. And it is these expectations which fuel incentives for improving the productivity of operators' resources. Therefore, to secure optimal allocation of operators' resources, managers are often interested in supporting their decisions by the use of academic methodologies.

When analyzing the productivity of their operations, retailers usually rely on aggregate measures like sale per unit of size or unit of labor. In operations research literature (e.g. Athanassopoulos and Ballantine 1995; Beamon 1999; Reynolds 2004), it is argued that the use of ratio analysis (common for managerial evaluation of performance) is not sufficient to properly assess the performance of analyzed decision making units because the major limitation of ratio analysis is its univariate nature. To deal with this drawback, our study applies a more comprehensive framework for assessing the performance of retail network units by comparing the results of non-parametric production frontier methods, parametric production frontier methods, and ratio analysis. Parametric methods are capable of handling single output-multiple input technology, and require specification of the production function form. The non-parametric method used in this work, however, allows for multiple input-multiple output technologies and does not require specification of the production function form. Moreover, the non-parametric method supplies information on returns to scale on an individual level. The use of parametric methods (Corrected Ordinary Least Squares - COLS and Stochastic Frontier Analysis - SFA) along with a non-parametric method (Data Envelopment Analysis - DEA) provides a means of assessing the robustness of estimated efficiency levels.

The retail units have only limited control over their outputs, which are mostly determined by the sales potential of the unit's location. Therefore, the appropriate 
behavioral objective for retail network managers would be input minimization, rather than output maximization. To determine the efficiency of retail network units, production frontier analysis assesses the actual levels of inputs with respect to the estimated optimal levels of inputs. This input-oriented efficiency measure detects managerial failures to minimize use of inputs for a given level of output. Moreover, this approach gives an indication of the possible gains from exploiting technical and scale efficiencies.

This technical efficiency and returns to scale study supports a wider scope project on the optimization of a mobile network operator retail chain. We focus on identifying returns to scale, because mobile network operators in environments with a high rate of change are constantly forced to grapple with competitors by creating economies of scale. Further, according to the managerial literature (e.g. Stabell and Fjeldstadt 1998) on chain value creation, key determinants of costs of the retail chain are capacity utilization and scale of operations.

This paper is organized as follows. Section two gives details of the retail technology and discusses the input-output specification used to model the production frontier. Section three lays out the theoretical DEA framework and specifies the linear programming problem used to evaluate the technical and scale efficiency of the retail units. It also provides a review of the parametric methodologies (COLS and SFA) used to test the hypothesis of constant returns to scale of the employed technology. The fourth section reports ratio analysis and production frontier results, and the fifth section concludes with a summary of policy implications.

\section{Retail technology}

A formulation of the DEA problem and specification of the production function form requires an understanding of the production process and the identification of production inputs and outputs, respectively. This section briefly describes the 
production function of the retail outlets and defines the corresponding measures of production inputs and outputs.

The key function of retail outlets of a mobile network operator is acquiring new subscriptions to services provided by the operator. The acquisition of a new customer involves the sale of a SIM card $^{1}$, a mobile phone (and accessories), and the selection of a price plan suiting the subscriber's preferences. While revenues reported by a store are derived from the sale of equipment (and prepaid credit vouchers), these are not considered to be the key output of the unit. ${ }^{2}$ Rather, definition of a key unit's output is motivated by the store's primary acquisition function. Once a customer signs up for one of the price plans (or purchases a prepaid card) he starts using the services provided by the network operator and he generates revenues that are collected either via a monthly bill or via the sale of prepaid vouchers. In fact, this revenue is also used to cover the costs of running retail stores; thus revenues collected from acquired subscribers represent the key (financial) benefit derived from the operation of retail stores. Therefore the number of SIMs sold and the monthly revenue generated by the number of subscribers acquired in a store were chosen as output measures for this study.

In total we use three different production output specifications. For two oneoutput models we use either the number of SIM cards sold to customers or the revenue generated by these customers, respectively. In the case of the two-output models (DEA only) we describe outputs together as SIM cards sold and revenue generated by customers using the sold SIM cards.

The mobile phone operator at the time of this study was running a retail network

\footnotetext{
${ }^{1}$ SIM, a Subscriber Identity Module, is a card commonly used in a GSM phone. The card holds a microchip that stores information and encrypts voice and data transmissions. The SIM card also stores data that identifies the caller to the network service provider.

${ }^{2}$ The biggest revenue item (from total revenue reported by a store), the handset revenue, would be a misleading output indicator as phones sold together with activation of a tariff plan are sold at subsidized prices and the margins (difference between retail and wholesale price) are hence in these cases negative. The negative handset margin is thus treated by the operator and the industry as a component of the Subscriber Acquisition Cost (SAC) rather than as revenue derived from providing services.
} 
with over forty outlets across the country and was considering closing or relocating some of the existing units as well as opening additional units at new locations. Some key questions management faces when setting up a retail outlet are: What should the size of the sales area be? How many sales people are required to achieve the sales potential in that unit's sales area? These two factors appear to be the key determinants of outlet performance, in addition to the regional and location aspects. ${ }^{3}$ At the same time, the costs of these two production factors represent $98 \%$ of the units' total operating costs. ${ }^{4}$ Therefore the number of sales representatives (employees) and the sales area of the store were identified as the production inputs. This specification of inputs is used for all models.

The stores' sizes and their locations were determined by the retail chain manager at the outset of the retail network roll out on the basis of the initial sales potential estimates of individual regions. The size of each location allows for a variable number of employees, up to the point of its capacity given by the sale area. The total headcount per individual store is decided jointly by the local store manager, regional manager, and central retail network manager. Based on the observed traffic pattern, the store manager is able to adjust the capacity of the sales force by drawing on part-time staff. Store opening hours are set so as to reflect the sales potential of the location; i.e. stores in shopping malls are open whole weekends, while stores in other locations are e.g. open for limited hours on Saturdays. As one employee represents 40 working hours per week, the measure of the number of employees captures the differences in opening hours across stores.

Following the literature on retail productivity, other criteria relevant for retail productivity were considered: employees' personal characteristics such as training level and motivation (e.g. Bush et al. 1990; Lusch and Serpkenci 1990); wage rate (Bucklin 1978) and attitudes (MecKenzie, Podsakoff, and Fetter 1993); and

\footnotetext{
${ }^{3}$ The regional aspects and sales potential of individual sales areas were assessed in a separate study and are beyond the scope of this paper.

${ }^{4}$ Utilities and site maintenance represent remaining units' costs.
} 
behavioral outcomes such as service quality (Parasuraman, Zeithaml, and Berry 1994) and assortment differences (Grewal et al. 1999). However, as explained below there is no evidence that these factors differ across the studied retail stores and employees; thus these characteristics are not helpful in explaining productivity variation across stores in our sample.

At the time of this study, strong market growth and increasing penetration had forced operators to allocate their resources primarily in acquiring subscribers. Acquisition is thus seen as the primary goal of the retail stores, and the work effort of the sales persons is stimulated by the incentives that reflect this goal. Because the incentives and overall reward scheme of the sales staff is centrally designed and is homogeneous across stores, the variable pay of the sales staff is driven by the number and value of the SIMs sold. The value of the SIM is measured by the (expected) revenue the sold SIM will generate, which in turn is proxied by the price tariff the customer with the given SIM subscribes to.

The time spent with an individual customer purchasing a specific service does not differ from location to location, but does differ from customer to customer due to the differences in tariffs being sold. The key discriminator here is the payment type associated with the tariff sold. The prepaid tariffs (also known as 'pay as you go' tariffs) take a shorter time to sell than do postpaid tariffs. Consumers with prepaid tariffs, as the name indicates, pay for the services in advance, i.e. before the services are consumed. Postpaid tariffs, by contrast, allow the subscribers to consume services before being charged for them. Postpaid fees are collected from these subscribers via invoices that are sent to their home addresses. This system requires that the customer register personal data with the operator (and often also finalization of the term specific service contract) and thus requires longer sales time. Postpaid tariffs bind subscribers to paying a regular monthly fee, thus guaranteeing the operator recurring monthly revenues which, as a consequence, increases the value of the postpaid customer above the prepaid one (it is common knowledge that 
mobile subscribers on prepaid tariffs generate on average lower monthly revenue than do postpaid subscribers). This fact is captured by the incentive scheme, and the longer time spent acquiring a postpaid subscriber is rewarded by the higher number of points earned by the sales staff for the acquiring of this type of customer.

However, the busiest locations may produce a perverse effect despite this feature of the incentive scheme. The extreme workload (high number of incoming shoppers) at these busy locations can cause the sales staff to go after quantity rather than quality of customers, as the number of incentive points earned is very high under these conditions. As a consequence the busy locations may sell a high volume of SIMs, though their average value may be lower compared to SIMs activated by other less busy stores whose locations show a smaller sales potential. We capture this specific feature of the retail sale technology in one of the DEA models by using two output measures: number of SIMs sold and total revenue generated by the store.

Even though some time of the sales staff is spent on serving the current subscribers, this is not seen as the primary goal of the store and does not take a big share of staff time; hence it is not reflected by the incentive scheme. Based on staff and store manager experience and on a comparison across stores, the share of time spent on service activities is minor and approximately the same in all stores (and varies across stores by about $+/-5 \%)$.

All sales persons must pass the same sales skills training so that the high quality of service is homogeneous and preserved across stores. ${ }^{5}$ Quality of service is measured regularly, and quality assurance test results from the time period of this study indicate that there is very small variation in key quality indicators across stores and sales persons. The consistently high and homogeneous quality of sales staff thus precludes this as a possible explanations for the varying degree of ef-

\footnotetext{
${ }^{5}$ Quality of both sale and product skills are ensured. Moreover, each introduction of new products or services by the operator is coupled with the appropriate product/service specific knowledge training of the sales staff.
} 
ficiency across stores. Homogeneity of the other service attributes (e.g. types of offered handsets) is ensured by the systems and technology supporting the seamless operation of all stores (e.g. central inventory system).

While the output potential (number of shoppers coming to the store) is assumed to be given and determined by the regional characteristics and intensity of the operator's nationwide advertising campaigns, the realization of that output potential is (assumed to be) the function of the input mix (quality of inputs is assumed homogeneous) and it is the optimum input mix we seek to identify for each location.

\subsection{Data description}

Table 1 in the Appendix summarizes the descriptive statistics of inputs and outputs used to specify the production mix. Stores in our sample were observed over a 3-month of steady mobile market growth. The 42 stores represent the total number of the operator's stores, and the number of SIMs reported are those sold over the period of one quarter of the year. The revenues reported were accounted for in the third month of the quarter following the sale (acquisition) period. The number of employees are cumulative over the 3-month period and thus reflect total manhour capacity devoted to sales activity in the time period we study. All variables are measured with minimum error as the information systems in place provide automatic data collection and their accuracy has been tested over time prior to the study period.

Figure 1 (see Appendix) presents the matrix of scatter plots for each pair of input and output variables. The high positive correlation between number of employees and both measures of output is clearly visible. However, the relationship is less clear when sales area is considered. While output seems to increase with number of employees, it does not seem to measure up with increasing sale area size. This observation clearly corresponds to the actual flexibility of input adjustments. 
The number of employees can be adjusted fairly flexibly to reflect the varying demand conditions of each store. However the size of the sale area is fixed over the time of the lease, and once the location and size of the store is decided (based on the initial estimates of the location's sales potential) there is limited possibility to adjust this production input.

This study (efficiency and input slack estimates) thus gauges the quality of two separate skills: the ability of the central manager to determine optimum sizelocation and total retail chain headcount mix, and the ability of individual retail store managers to optimally schedule employees. The identified labor input slacks can thus be directly translated into a reduction of employee working hours. The size of sale areas are, however, more difficult to adjust in practice. It is up to the manager to consider the possibilities for store size adjustment or alternative solutions in addressing low incoming customer traffic if slacks are small. When slacks are substantial, store relocation may be inevitable to avoid further wasteful consumption of resources.

\section{Methodology}

There is no single widely accepted approach to assessing retail store productivity (Donthu and Yoo 1998). However, in recent retailing studies (e.g. Donthu and Yoo 1998; Reynolds 2004) production frontier methodologies are most frequently used. In this paper we use both parametric and non-parametric production frontier methods to create a comprehensive framework for technical efficiency analysis.

In their original paper on production frontier methods, Marschak and Andrews (1944) sketched out the terms "technical" and "economic efficiency" (paragraph 1 and 11) of a firm. Later, Farrell (1957) defined the efficiency of a decision making unit (DMU), which consists of two components: technical efficiency (TE) and allocative efficiency (AE). In Farrell's efficiency concept, overall efficiency (OE) is 
defined as the multiplicative combination of technical and allocative efficiency, so that $\mathrm{OE}=\mathrm{TE}^{*} \mathrm{AE}$. Allocative efficiency expresses the extent to which an analyzed DMU uses its inputs in proportions which minimize the costs of production, assuming that the unit is already fully technically efficient. Technical efficiency measures the extent to which inputs are converted to outputs relative to the best practice frontier.

An important feature of the retailing network in a competitive market is that the retail stores must meet the demand for their services but are not able to choose the level of output they will offer due to competition limitations. Further in our case, we have to abstract from the role of prices of mobile network services because the retail units do not affect these prices; all retail units are offering the same services for the same prices. Regional and location aspects (demographic, social, economic and competitive supply patterns of towns/districts) that determine the sales level of mobile network services by retail units are considered to be beyond the unit's control. These facts provide a rationale for considering the levels of outputs as given by local characteristics and by the general operator's sales strategy. Given the exogeneity of the output levels, the retail network maximizes profit simply by minimizing the levels of used inputs for producing a given level of output.

We also abstract from the role of prices in allocation of resources because rent and size of the retail unit is predominantly affected by location characteristics and availability of space for rent. Due to these restrictions, we do not assume that the unit's location and size is chosen with respect to allocative efficiency. Therefore, rather than considering the cost or profit efficiency level of retail units, we focus our analysis on the technical efficiency of units, especially input efficiency.

The following sections review input-oriented DEA methodology and two parametric methods (COLS and SFA) used to search for the production frontier that allows us to evaluate technical and scale efficiency of retail stores. 


\subsection{Non-parametric frontier approach: DEA}

Using Farrell's (1957) concept, Charnes, Cooper, and Rhodes (1978) introduced the first DEA model to evaluate technical efficiency in a multi input-output environment. Since then, the CCR model and its modifications have become a widely used tool for operations analysis and production frontier search in many sectors including schools, hospitals and banks. The DEA models measure the efficiency of DMUs by identifying the best performing units. These best performing units are then used to construct the "best practice frontier" through a piecewise linear envelopment of observed data. Therefore the efficiency scores estimated by the DEA models are relative measures of efficiency within the sample of the analyzed DMUs.

The DEA approach assumes that each of the considered DMUs is described by a vector $x_{j}, x_{j}=\left(x_{1 j}, \ldots, x_{m j}\right)^{T}$ of $m$ inputs amounts that are used to produce $s$ outputs in amounts described by vector $y_{j}, y_{j}=\left(y_{1 j}, \ldots, y_{s j}\right)^{T}$. To aggregate these vectors into matrices of inputs and outputs the following notation will be used:

$$
\begin{array}{ll}
\text { matrix of inputs vectors } & X_{m \times n}=\left(x_{1}, \ldots, x_{n}\right) \\
i^{\text {th }} \text { row of "input" matrix } X & { }_{i} x=\left(x_{i 1}, \ldots, x_{i n}\right), i=1, \ldots, m \\
\text { matrix of outputs vectors } & Y_{r \times n}=\left(y_{1}, \ldots, y_{n}\right) \\
r^{\text {th }} \text { row of "output" matrix } Y & { }_{r} y=\left(y_{r 1}, \ldots, y_{r n}\right), r=1, \ldots, s .
\end{array}
$$

When using the DEA approach to search for the "best practice frontier", it is assumed that the set of production mixes used by DMUs is described by the production possibility set

$$
T=\{(x, y) \mid \text { using inputs } x \geq 0 \text { outputs } y \geq 0 \text { are produced }\}
$$

and it is assumed that the technology set has the following properties:

1. Convexity: If $\left(x_{j}, y_{j}\right) \in T, j=1, \ldots, n$ and $\lambda \in \mathbb{R}_{+}^{n}, \Rightarrow(X \lambda, Y \lambda) \in T$.

2. Inefficiency property: If $(x, y) \in T$ and $\bar{x} \geq x$, then $(\bar{x}, y) \in T$. 
If $(x, y) \in T$ and $\bar{y} \leq y$ then $(x, \bar{y}) \in T$.

3. Minimum extrapolation: $T$ is the intersection of all sets satisfying the convexity and inefficiency property such that each of the observed production mix $\left(x_{j}, y_{j}\right) \in T, j=1, \ldots, n$.

4. No free lunch: $(0, y) \notin T$, for $y>0$.

The production frontier ("best practice frontier") determines the minimum level of inputs needed to produce a given level of outputs. The input-oriented DEA models examine the levels of inputs needed for the production of a DMU's output mix, and the efficiency measure indicates whether the DMU under consideration uses the minimum necessary level of inputs. The simplest input-oriented efficiency score of the $\mathrm{DMU}_{j}$ measures the maximum proportional reduction of inputs that allow production of the same output mix as the examined $D M U_{j}$. However, due to its simplicity, this measure fails to uniquely identify efficient units. Therefore, we will use a more complex efficiency measure, described later.

We use the input-oriented DEA models to evaluate the input-oriented pure technical efficiency and scale efficiency score of the $\mathrm{DMU}_{j}$, for $j=1, \ldots, n$ which are characterized by the following general linear programming problem:

$$
\begin{array}{rc}
\min _{\lambda_{j}, \theta_{j}, e_{j}, s_{j}} & \theta_{j}-\epsilon\left(\mathbf{1}^{T} e_{j}+\mathbf{1}^{T} s_{j}\right) \\
\text { s.t. } \quad & \theta_{j} x_{i j}-{ }_{i} x \lambda_{j}-e_{i j}=0, \quad i=1, \ldots, m ; \\
r & y \lambda_{j}-s_{r j}=y_{r j}, \quad r=1, \ldots, s ; \\
\varphi\left(\mathbf{1}^{T} \lambda_{j}\right) & =\varphi ; \\
\lambda_{j}, e_{j}, s_{j} \geq 0
\end{array}
$$

where $\lambda_{j} \in \mathbb{R}_{+}^{n}$ (intensity variable), $\theta_{j} \in \mathbb{R}_{+}$(proportional input reduction), $e_{j} \in \mathbb{R}_{+}^{m}$ (non-proportional input excess), $s_{j} \in \mathbb{R}_{+}^{s}$ (output slack), $\varphi$ takes the value 0 for the CCR input-oriented model introduced by Charnes, Cooper, and 
Rhodes (1978) and 1 for the BCC input-oriented model by Banker, Charnes, and Cooper (1984). ${ }^{6}$ Formulation of these models as in Problem 1 is referred to as envelopment form because the optimal solution $\left(\theta_{j}^{*}, \lambda_{j}^{*}, e_{j}^{*}, s_{j}^{*}\right) \in \mathbb{R}_{+}^{1+n+m+s}$ identifies the projection of $\mathrm{DMU}_{j}$ on the envelopment surface ("best practice frontier") in the direction of proportional inputs reduction.

$\theta_{j}^{*}$ expresses the minimal, proportionally reduced, levels of inputs for the $\mathrm{DMU}_{j}$ while keeping the outputs at the same levels, in order to improve the technical efficiency of this unit. ${ }^{7}$ Low value of $\theta_{j}^{*}$ indicates excessive use of all inputs in the production mix. This property of $\theta_{j}^{*}$ provides a rationale for using $\theta_{j}^{*}$ as an efficiency measure. Due to the fact that this measure ignores non-proportional reduction of inputs, additional conditions on input excess and output slack are needed to identify efficient units.

The constant $\epsilon$ in Problem 1 is a non-Archimedean infinitesimal that allows the problems of the search for maximal input reduction and the search for frontier projection to be condensed into a single optimization problem. In a chapter on computational aspects of the DEA, Charnes et al. (1994) argue that the value of $\epsilon$ should be determined by an analyzed sample. Therefore, we choose $\epsilon=10^{-6} \min _{j=1, \ldots, n} 1 /\left(\sum_{i=1, \ldots, m} x_{i j}\right)$ for our analysis. This choice of $\epsilon$ means that proportional input reduction effectively preempts the optimization that involves non-proportional slacks $e_{j}$ and $s_{j}$. The DEA models as stated in Problem 1 are solved by implementing the primal-dual interior point method designed by Mehro$\operatorname{tra}(1992) .^{8}$

The elements $e_{i j}$ express the input excess for each of the inputs, and the vector $e_{j} \in \mathbb{R}_{+}^{m}$ is formed to express the non-proportional input excess for $D M U_{j}$ 's inputoutput mix. At least one element of $e_{j}^{*}$ (part of the optimal solution) should be zero, otherwise there exists the possibility of proportional input reduction. Likewise

\footnotetext{
${ }^{6}$ Here, $\mathbb{R}_{+}$denotes the set of positive real numbers and $\mathbf{1}$ is a column vector of ones.

${ }^{7} 1-\theta_{j}^{*}$ expresses the maximal proportional input reduction of input levels.

${ }^{8}$ To analyze sensitivity of solutions with respect to the choice of $\epsilon$, we used $\epsilon=0$ to calculate new efficiency scores. No significant changes in efficiency scores were recorded.
} 
for outputs, the outputs slacks $s_{r j}$ form a vector of outputs slacks $s_{j} \in \mathbb{R}_{+}^{s}$ and $s_{j}^{*}$ expresses the possible output augmentation. Further, individual slack analysis can help retail managers allocate resources more effectively and improve performance.

The efficiency of $\mathrm{DMU}_{j}$ is evaluated using the optimal solution $\left(\lambda_{j}^{*}, \theta_{j}^{*}, e_{j}^{*}, s_{j}^{*}\right)$ of Problem 1 under the assumption of the selected returns to scale (RTS) type. In the DEA literature (Charnes et al. 1994; Banker, Charnes, and Cooper 1984; Sueyoshi 1997) the efficiency of $\mathrm{DMU}_{j}$ is evaluated according to the following theorem:

Theorem 1. Efficient $D M U_{j}$ : The $D M U_{j}$ is DEA efficient if both of the following conditions are satisfied: 1) $\theta_{j}^{*}=1$; and 2) All values of slacks are zero: $\mathbf{1}^{T} e_{j}^{*}=0$ and $\mathbf{1}^{T} s_{j}^{*}=0$. Otherwise $D M U_{j}$ is inefficient.

If $\mathrm{DMU}_{j}$ is identified as inefficient according to Theorem 1, the optimal values of slacks $e_{j}^{*}, s_{j}^{*}$ and the optimal value $\theta_{j}^{*}$ identify the sources and levels of present inefficiency. ${ }^{9}$ To take into account the presence of proportional and non-proportional slacks we use the efficiency measure introduced by Tone (1993) to evaluate efficiency in a comprehensive yet simplified fashion by defining the following input-oriented efficiency measure:

$$
\chi_{j}=\left(\theta_{j}^{*}-\frac{\mathbf{1}^{T} e_{j}^{*}}{\mathbf{1}^{T} x_{j}}\right) \frac{\mathbf{1}^{T} y_{j}}{\mathbf{1}^{T} Y \lambda_{j}^{*}}
$$

This efficiency measure has the following properties:

1. $\chi_{j}=1 \Leftrightarrow$ The $\mathrm{DMU}_{j}$ is efficient

2. $\chi_{j}=\theta_{j}^{*} \Leftrightarrow$ The values of all slacks are zero

3. $0 \leq \chi_{j} \leq 1$

4. $\chi_{j}$ is a units invariant measure

${ }^{9}$ According to Theorem $1, \theta_{j}^{*}=1$ is a necessary condition but not sufficient to evaluate the $\mathrm{DMU}_{j}$ as efficient. Consider the case of $\mathrm{DMU}_{6}$ in Figure 2, where $\theta_{6}^{*}(V R S)=1$ but because $e_{j}^{*}>0$ this unit is dominated in efficiency by $\mathrm{DMU}_{4}$. 
5. $\chi_{j}$ is monotonically increasing in inputs and outputs of $\mathrm{DMU}_{j}$

6. $\chi_{j}$ is decreasing in the relative values of the slacks.

The first efficiency measure property guarantees that this efficiency measure uniquely identifies the efficient DMU while the fourth, fifth and sixth properties provide a rationale for use of this measure to create an efficiency ranking for analyzed DMUs.

Further, after identifying efficient DMUs and identifying projections onto the production frontier (potential efficiency improvements), we use the DEA methodology to examine scale efficiencies of DMUs. Scale efficiency measures the extent to which $\mathrm{DMU}_{j}$ can take advantage of returns to scale by a change in its size towards the optimal scale, characterized by the constant returns to scale property. ${ }^{10}$

Charnes et al. (1994) and Sueyoshi (1997) provide an extensive summary of the relationships between various DEA model specifications and estimated types of efficiency (technical, pure technical, scale, cost, and allocative). Following the outlined methodology, we estimate the pure technical efficiency of $\mathrm{DMU}_{j}$ using the BCC model (setting $\varphi=1$ in Problem 1), and the technical and scale efficiency by utilizing the CCR model (setting $\varphi=0$ in Problem 1). Because of the multiplicative nature of technical efficiency, the scale efficiency of production frontier elements can be evaluated by breaking down the technical efficiency score into a scale of operations component and a "pure" technical efficiency score.

We also estimate the model under the assumption of non-increasing returns to scale (NIRS). Such a model is derived from Problem 1 by replacing the intensity variable constraint with inequality $\mathbf{1}^{T} \lambda_{j} \leq 1$. For these input-oriented DEA models the following property for optimal solution $\theta_{j}^{*}$ holds:

$$
0<\theta_{j}^{*}(C R S) \leq \theta_{j}^{*}(N I R S) \leq \theta_{j}^{*}(V R S) \leq 1 .
$$

\footnotetext{
${ }^{10}$ As defined in the glossary of the Steering Committee for the Review of Commonwealth/State Service Provision (1997).
} 
The amount of scale inefficiency can be imagined as the distance between the constant returns to scale (CRS) and the variable returns to scale (VRS) frontier, because this distance is determined by the scale efficiency component of technical efficiency. Figure 2 illustrates the comparison of the CRS frontier (CCR model) with the VRS frontier (BCC model). In Figure 2, the VRS frontier and production possibility set are divided according to the RTS type of frontier elements into subsets of increasing returns to scale (IRS, dashed line), scale efficient (bold solid line) and decreasing returns to scale (DRS, dot-dash line). Elements from the horizontally-shaded area can be projected in the input reduction direction onto the part of the frontier with the IRS property, and from the vertically-shaded area onto the part of the frontier with the DRS property. Projections of elements from the cross-shaded area belong to the scale efficient part of the production frontier. Figure 2 thus illustrates the situation in which $\mathrm{DMU}_{2}$ and $\mathrm{DMU}_{3}$ are scale efficient units, whereas the rest of the analyzed units are scale inefficient due to the presence of either IRS or DRS.

As illustrated above, the analyzed $\mathrm{DMU}_{j}$ can be identified as operating in the region of the production possibility set with a) increasing RTS, b) decreasing RTS or c) scale efficiency property. In addition to quantifying the scale efficiency level we also determine for each unit the type of RTS region it operates in. The literature on RTS identification presents various approaches to extracting qualitative information on returns to scale of the frontier. Löthgren and Tambour (1996) summarize four different (but equivalent) approaches to estimating returns to scale using a primal or dual solution to the DEA models stated in Problem 1. To determine the RTS type for an individual retail unit we employ the scale efficiency method. The concept of the scale efficiency method introduced by Färe and Grosskopf (1985) is discussed in detail by Zhu and Shen (1995) and can be given as the following theorem from Löthgren and Tambour (1996):

Theorem 2. Scale efficiency method: For the specific $D M U_{j}$ let define scale ef- 
ficiency measure $S E_{j}=\frac{\theta_{j}^{*}(C R S)}{\theta_{j}^{*}(V R S)}$. Then $S E_{j}=1$ iff the $D M U_{j}$ exhibits $C R S$ (the $D M U_{j}$ is scale efficient); if $S E_{j}<1$, then $\frac{\theta_{j}^{*}(C R S)}{\theta_{j}^{*}(N I R S)}=1$ iff the $D M U_{j}$ exhibits IRS; if $S E_{j}<1$, then $\frac{\theta_{j}^{*}(C R S)}{\theta_{j}^{*}(N I R S)}<1$ iff the DMU $U_{j}$ exhibits DRS.

An important part of the DEA analysis is the test for sensitivity of results to the selection of inputs and outputs for productivity mix description and returns to scale assumption. For this purpose efficiency scores are calculated using alternative model specifications. Besides the descriptive statistics comparison, the sensitivity of efficiency rankings constructed according to the efficiency measure of Tone (1993) is examined by use of the Spearman rank correlation coefficient. The rank correlation coefficient and statistics by Spearman (1904) test the hypothesis of rank independence. Spearman (1904) correlation coefficient is commonly used to compare rankings in statistical studies. ${ }^{11}$

\subsection{Parametric frontier approach: COLS}

Further, to assess the robustness of efficiency and RTS estimates, we complement the DEA methodology with results of the parametric production frontier approach using corrected ordinary least squares (COLS) and stochastic frontier (SFA) methodology. Winsten (1975), in his discussion of Farrell's (1957) paper, suggested a parametric alternative to DEA that is based on a two-stage estimation of production frontier, known as corrected ordinary least squares.

The deterministic production frontier of Cobb-Douglas production technology with variable returns to scale is represented by the following model:

$$
\ln \left(y_{j}\right)=\beta_{0}+\sum_{k=1}^{m} \ln \left(x_{j k}\right) \beta_{j}-u_{j}
$$

where the inputs $x_{j k} \in \mathbb{R}_{+}$are used to produce single output $y_{j} \in \mathbb{R}_{+}$for $j=1, \ldots, n$

\footnotetext{
${ }^{11}$ For implementation details of the Spearman rank correlation coefficient and statistics, see the manual by Stata Corporation (2003). For properties of the correlation coefficient see Kendall (1955).
} 
and inefficiency component $u_{j} \geq 0$ is assumed to be iid distributed with nonnegative mean and constant variance. Equation 4 is in the first stage estimated by OLS, which produces the unbiased and consistent slope parameters estimates of the frontier model. In this stage, a consistent but biased estimate of intercept parameter $\beta_{0}$ is obtained.

In the second stage, the unbiased intercept is estimated consistently by:

$$
\hat{\beta}_{0}^{*}=\hat{\beta}_{0}+\max _{j}\left\{\hat{u}_{j}\right\}
$$

and the OLS residuals are corrected according to:

$$
-\hat{u}_{j}^{*}=\hat{u}_{j}-\max _{j}\left\{\hat{u}_{j}\right\}
$$

This correction makes all residuals non-negative and at least one of them zero. The corrected residuals $-\hat{u}_{j}^{*}$ are used to provide consistent estimates of technical efficiency. The technical efficiency of producer $i$ is calculated according to the following function:

$$
T E(C O L S)_{j}=\exp \left(-\hat{u}_{j}^{*}\right)
$$

Using the technical efficiency score $T E(C O L S)_{j}$ we construct an efficiency ranking and compare this ranking to the DEA efficiency ranking to evaluate the sensitivity of our results.

\subsection{Parametric frontier approach: SFA}

The COLS approach, summarized in the previous section, does not take into account the possible effect of random shocks that may also cause variation in output. Therefore, we also employ a method of stochastic frontier which accounts for random shocks and technical inefficiency effect on variation in output. The stochastic frontier analysis method (SFA) was first introduced by Meeusen and van den Broeck 
(1977) and Aigner, Lovell, and Schmidt (1977). Since then, SFA has become a very popular tool that competes with the DEA approach in estimating production frontiers.

Assuming that the production function is linear in logarithms, the stochastic production frontier can be defined as follows:

$$
\ln \left(y_{j}\right)=\beta_{0}+\sum_{i=1}^{m} \beta_{i} \ln \left(x_{i j}\right)+v_{j}-u_{j}
$$

where $u_{j}$ represents the non-negative technical inefficiency component and $v_{j}$ is the symmetric two-sided random shock component.

Various specifications of the inefficiency term distribution lead to distinct frontier models. The most popular are half-normal $\left(u_{j}\right.$ iid $\left.N^{+}\left(0, \sigma_{u}^{2}\right)\right)$, truncated normal $\left(u_{j}\right.$ is $i i d$ with $N\left(\mu, \sigma_{u}^{2}\right)$ truncated at 0$)$ and exponential model $\left(u_{j}\right.$ iid exponentially distributed). We estimate these models by the maximum likelihood method.

Based on Kumbhakar and Lovell's (2000) remark on the low sensitivity of efficiency ranking to inefficiency distributional assumptions (confirmed in our sample), we estimate the stochastic production frontier under the assumption of a halfnormal distribution of the inefficiency term. Under this assumption the likelihoodratio test is used to test for the presence of an inefficiency component in the model. This test compares values of likelihood functions under $H_{0}: \sigma_{u}^{2}=0$ against alternative hypothesis $H_{1}: \sigma_{u}^{2}>0$. For more details on one-sided likelihood-ratio test statistics see Gutierrez, Carter, and Drukker (2001).

In addition to assessing the robustness of efficiency estimates, we use the deterministic (COLS) and stochastic (SFA) frontier methods to validate the conclusions of data envelopment analysis on returns to scale. To complete the parametric frontier analysis, we test the null hypothesis that retail units employ CRS technology by use of the Wald test (Kmenta 1990) to determine if the sum of production factor 
elasticities sums to 1 (testing restriction $\sum_{k=1}^{m} \beta_{k}=1$ ).

\section{Results}

In this section a summary of performance analysis results obtained by the DEA and parametric production frontier methodology is presented. Ratio analysis is discussed as well. For all technology specifications, inputs are described by the size of the sales area and the number of employees. As mentioned in previous sections, we use three different specifications of outputs to describe the retail technology of mobile network services. ${ }^{12}$

To assess technical efficiency we constructed four output/input ratios and ranked units according to these four productivity indicators. Results of this analysis are summarized in Table 2. For each ratio four top, middle, and bottom performing units are shown. There are two ratios per each output. We report the Spearman rank correlation coefficients for each output ratio and a low consistency of rankings is observed across ratio measures $(0.2811$ and 0.4661$)$ with respect to choice of output. These results illustrate the problem with the univariate nature of ratio analysis. As mentioned in the introduction, ratio analysis is not capable of capturing the multivariate nature of the considered retailing technology. These results thus provide a rationale for using more complex measures of productivity.

Using three different specifications of outputs we first compute efficiency scores by the input-oriented DEA models. Two models use a single output specification: 1) number of SIMs sold (referred to as SIMs model), and 2) revenue generated by acquired subscribers (referred to as Revenue model). The third model uses two outputs: number of SIMs sold and revenue generated by customers owning these SIMs (referred to as SIMs\&Revenue model). To estimate the production frontier under the SFA and COLS approach, we use only the first and second one-output

\footnotetext{
${ }^{12}$ Descriptive statistics of the models' inputs and outputs are summarized in Table 1.
} 
model specification.

Table 3 summarizes the descriptive statistics for the efficiency scores $\left(\chi_{j}\right)$, technical and scale efficiency $\left(\theta_{C C R}\right)$, pure technical efficiency $\left(\theta_{B C C}\right)$ and scale efficiency for all three specifications of the DEA models. Table 3 shows that on average the retail units are from 88 to $94 \%$ scale efficient and that average pure technical efficiency $(\theta)$ ranges from 52 to $58 \%$ depending on model specification. This result suggests that pure technical inefficiency is the main source of technical inefficiency and that DMUs on average are operating close to full scale efficiency.

We used the efficiency score $\chi_{j}$ to create performance rankings of DMUs. We assessed the sensitivity of results with respect to model specification by calculating Spearman rank correlation coefficients and by testing statistics for significance of rank correlation coefficients. To assess the extent of correlation we used Mortimer's (2002) review of studies on comparison of parametric and non-parametric methods as a benchmark. From analysis of the relation between sample size and extent of rank correlation in studies reviewed by Mortimer (2002), we were not able to identify any bias in extent of correlation with respect to sample size. In general, for values of Spearman rank correlation of 0.9 to 1 , the correlation is considered very strong; for values between 0.7 and 0.9 , correlation is considered strong; and for values between 0.5 and 0.7 , correlation is considered moderate.

The robustness of results was also tested by recalculating scores after the units identified as efficient and outlier units were removed from the full sample (42 observations). The sample of 39 observations used in the test focused on the consistency of DEA results, where we removed 3 units from the full sample that were identified as efficient by the 2 outputs- 2 inputs models. Further, we removed the four busiest sales locations according to a complementary study on store location aspects, where these four stores acquired a high number of customers (high number of SIMs acquired) when compared to the rest of the stores. The decision to remove these four units is also supported by hat matrix analysis, when these units are char- 
acterized by high values of leverage $(0.1496-0.3536$, the small sample cutoff $3 p / n$ suggested by Vellman and Welsch (1981), is 0.1428) and Cook's distance (0.22760.7083, while the cutoff 4/(n-k-1), suggested by Belsey, Kuh, and Welsch (1980), is 0.1025$)$.

Table 4 shows a summary of Spearman rank correlation coefficients for all considered models under either a CRS or VRS assumption. All estimated correlation coefficients are significant, and the high values of correlation coefficients suggest a low sensitivity of results to inputs and outputs specification among the considered models. Spearman's ranking correlation coefficient for these DEA technical efficiency rankings ranges from 0.7543 to 0.9728 in the case of SIMs models, $0.7115-0.9882$ in the Revenue model and $0.7816-0.9882$ for the SIMs\&Revenue model.

The differences between $\theta_{C C R}$ and $\theta_{B C C}$ suggest that after eliminating pure technical inefficiency (projecting observations onto the VRS frontier) inputs can be reduced on average by an additional 4-8\% without affecting level of outputs when CRS technology is used. Table 5 presents a detailed view on computed input reduction parameters and scale efficiency scores. The results presented in Table 5 are consistent with ordering condition 3 on theta. Table 5 also shows the levels of scale efficiency in the SE-score column.

The differences between means of efficiency scores $\left(\chi_{j}\right)$ and means of proportional reduction parameters $\left(\theta_{j}\right)$ within the model specification arise from the presence of non-proportional slacks when searching for efficiency improvements. As mentioned in the methodology section, this information can be used to predict additional performance improvement. To specify sources of this improvement, we present summary statistics of non-proportional slacks in Table 6. From this summary it follows that adjustments in store size can be the most important driver of possible performance improvements.

These results, as presented above, imply that retail network costs can be re- 
duced more if retail units were to emulate "best practice" rather than trying to adjust for scale efficiency of operations. These results are in line with other retail studies (Athanassopoulos and Ballantine 1995; Donthu and Yoo 1998) which conclude that reductions in cost arising from the realization of economies of scale are less important than the costs saved when a retailing network undertakes improvements in technical efficiency.

A summary of RTS identification by the DEA method is presented in Table 7. These results reveal that a majority of retail units appears to be operating in the decreasing returns to scale region of the production possibility set when the input reduction objective is imposed. This conclusion indicates the presence of economies of scale in the operation of individual retail stores.

The RTS identification results obtained by the DEA are supported by tests of the hypothesis that retail units employ CRS retail technology. To do this, we employed a parametric (COLS and SFA) technique. Two one-output models of production frontier were estimated. As mentioned above, we used the same outputs as in the one-output DEA models; both inputs and outputs are expressed in terms of logarithms (output was defined in terms of log of revenues and log of number of SIMs acquired, respectively). Tables 8 and 9 present the results of this estimation, while Table 10 summarizes the technical efficiency scores estimated by the parametric method. The estimated input elasticities do not significantly vary across the parametric methods. However, based on a log-likelihood ratio test we have to accept the hypothesis of no presence of an inefficiency component for the SFA model. As Schmidt and Sickles (1984) note, estimation of the cross-sectional stochastic frontier model is based on strong distributional assumptions of statistical noise and inefficiency components of the error term. Therefore, we attribute the failure to identify the asymmetric inefficiency component under the SFA model in this sample to the negligible skewness of inefficiency distribution.

Figure 3 illustrates the distribution of technical efficiency and compares para- 
metric (COLS) and non-parametric (DEA) methods. The density estimates reveal patterns typical for efficiency scores from the DEA approach, where the peak close to unity is due to efficient DMUs that are used to identify the production possibility frontier. Therefore, it is more appropriate to compare rankings of technical efficiency scores that result from parametric and non-parametric methods. These results are presented in Table 11.

Table 12 reports the results of testing for the prevailing type of returns to scale among retail units. Based on the Wald test, the null hypothesis of CRS was rejected. The sum of the elasticities of output with respect to inputs generated an estimated scale elasticity. The values of elasticities sums were less than one, which supports the DEA results regarding the presence of decreasing returns to scale.

The fact that the DRS property prevails for the majority of retail stores suggests that further expansion of units' operation size would lead to a less than proportional increase in outputs and that units may become even less effective. In this case, contraction in the size of retail store operations may increase their efficiency levels at the cost of a less than proportional reduction of achieved output levels.

To test the sensitivity of results to the presence of the busiest units, Table 13 and Table 14 present results of the parametric approach when a reduced sample of 38 observations is used. With this reduced sample, based on the log-likelihood ratio test we were able to reject the hypothesis of no presence of the technical inefficiency component in the SFA model.

Table 15 summarizes the results of technical efficiency estimation using a reduced sample under the DEA, COLS and SFA approaches. Estimated average technical efficiency ranges from 0.5253 to 0.6986 . We report only the results for technical efficiency scores under the VRS assumption because, according to test results presented in Table 16, we were able to reject the hypothesis of CRS technology. Figure 4 shows estimates of distributions of technical efficiency scores. Again, to assess the consistency of technical efficiency results, we use ranking correlations. 
The ranking correlations for reduced sample ranks are summarized in Table 17. The extent of rank correlation (Spearman rank correlation ranges from 0.67 to 0.98 ) and the fact that we were able to reject the hypothesis of rank independence for all cases (at 1\% significance level) lead us to conclude that the technical efficiency rankings are robust with respect to the choice of frontier approach.

Further, when comparing results for the reduced sample with results from the full sample presented in Tables 3 and 10, we observe an upward shift in the average and minimal technical efficiency score. This fact is consistent with the nature of technical efficiency estimates used in this analysis. To analyze the sensitivity of rankings, we compare rankings for the full and reduced sample by use of ranking correlation coefficients. The ranking correlation coefficients for both samples are summarized in Table 18. These results allow us to consider our results as robust with respect to the choice of productivity frontier approach and to model specification across the full and reduced samples.

Assessing Figure 5 and Figure 6, where type of returns to scale is drawn against the level of input, we conclude that the overall DRS property of DMUs results from the DRS property of size of store. This conclusion supports the ratio analysis results indicating that sales per square meter decrease with size of the store. However, we cannot make a straightforward conclusion about the prevailing returns to scale property of labor input characterized by number of employees.

Finally, the relation between levels of inputs used for the production and efficiency scores is illustrated in Figures 7 and 8. We observe that the highest efficiency scores are attained by units with a relatively small size (Figure 7). Similarly, as in the case of the relation of the RTS type to number of employees, we cannot draw a straightforward conclusion about the effect the number of employees has on the efficiency of retail store 8 .

Figures 9 and 10 illustrate the ratio analysis of performance evaluation and links it to the DEA approach to efficiency evaluation. These figures show DMUs 
in the space of the output per unit of input: SIMs sold per employee and SIMs sold per square meter in Figure 9, and revenue generated per employee and revenue generated per square meter in Figure 10. To link the ratio analysis of performance evaluation with the DEA results, we labelled data points in Figures 9 and 10 with the DEA efficiency scores. Figure 9 and Figure 10 reveal that units considered highly performing according to ratio analysis also show high DEA efficiency scores. Efficiency growth in this space is indicated by the thick arrow on the bottom of each graph. Productivity ratios (output per unit of input) are highly correlated with efficiency scores.

In general, the higher the output per square meter and/or output per employee, the higher the efficiency score. Lines that divide the graph area into four parts are meant to separate the units that are in the upper quartile of maximal level of output per unit of input. Based on ratio analysis, units in the outer regions are considered units with high efficiency. This reasoning is confirmed by the high DEA efficiency score of these outer units.

\section{Conclusion}

The main objective of this paper was to demonstrate the use of a complex framework for performance analysis by estimating technical and scale efficiency of individual stores in the retail network of a mobile network operator. This framework allowed us to overcome the shortcomings arising from the univariate nature of ratio analysis. The goal of this technical efficiency study was to facilitate the optimization of resource allocation so that retail units consume their inputs in an optimal mix to provide retail services.

We quantified the possible efficiency improvements of inefficient retail stores, using an equi-proportional input reduction approach. Efficiency improvements can be driven by improvements in better operational practices (improvements in 
headcount planning, adjusting for variation in sales over time) or in adjustments of the production mix (size of sales area per employee). We also identified the returns to scale type of analyzed units as additional information for the adjustment of production mix size. The information on the RTS type allows managers to decide on future expansion or contraction in size of operations after the unit adopts the practice of efficient production mix. Analysis of non-proportional slacks indicated that reduction in store size can yield substantial improvements in technical (and likely also in cost efficiency) for some of the larger stores. Robustness of the DEA results is supported by results from parametric frontier methods (COLS and SFA).

In their performance evaluation of the retail units, managers can put too much emphasis on measuring output levels alone. However, there may be well managed stores whose performance can be negatively affected by exogenous factors, or a poorly managed store helped by favorable environmental factors. Low levels of outputs, therefore, are not sufficient to judge on retail unit efficiency; to make decisions about units we hence assessed the efficiency level and outputs levels together as two key performance measures.

To assess these performance measures together, we placed the retail units in an outputs-efficiency space as displayed in Figure 11 and Figure 12. In both figures the space is divided into four quadrants at mean values. Retail units located in the "Stars" quadrant are those with the highest efficiency scores and which are probably operating in a favorable economic environment. Opposite to this is the "Cows" quadrant, which contains low efficiency units probably located in an unfavorable environment (area with low sales potential). The "Dogs" quadrant contains efficiently operated retail units with lower levels of outputs, likely due to being located in a low sales potential area. The "Sleepers" quadrant contains retail units that show high levels of outputs, but this has more to do with favorable environmental conditions than with good management. Units located in the "Sleepers" quadrant are candidates for efficiency improvements that may lead to even greater profits. 
Managers should attempt to increase the efficiency of stores in these locations.

From a comparison of the extent of scale inefficiency and pure technical inefficiency, we conclude that managers should implement the operational practices of the technically efficient units rather than exploit economies of scale to improve retail network performance. This conclusion is supported by the results of RTS identification, which indicates that the majority of retail units is operating in the DRS region.

We argue that the DEA and parametric production frontier study permits a more thorough and complex understanding of the assessment of retail store performance than does simple ratio analysis. Finally, the use of a "best practice" approach to predicting the operations of retail stores allows managers to set realistic and individual goals based on a store-specific profile.

\section{References}

Aigner, Dennis, C. A. Knox Lovell, and Peter Schmidt. 1977. "Formulation and Estimation of Stochastic Frontier Production Function Models." Journal of Econometrics 6 (1): 21-37 (July).

Athanassopoulos, Antreas D., and Joan A. Ballantine. 1995. "Ratio and Frontier Analysis for Assessing Corporate Performance: Evidence from the Grocery Industry in the UK." Journal of Operational Research Society 46:427-440.

Banker, R. D., Abraham Charnes, and William W. Cooper. 1984. "Some Models for Estimating Technical and Scale Inefficiencies in Data Envelopment Analysis." Management Science 30:1078-192.

Beamon, Benita M. 1999. "A Model and Measurement Approach for Studying Retail Productivity." International Journal of Operations and Production Management 19 (3): 275-292.

Belsey, D.A., E. Kuh, and R.E. Welsch. 1980. Regression Diagnostics: Identifying Influential Data and Sources of Colinearity. New York: John Wiley \& Sons.

Bucklin, Louis P. 1978. Productivity in Marketing. Chicago: American Marketing Association.

Bush, Robert P., Alan J. Bush, David J. Ortinau, and Joseph F. Hair. 1990. "Developing A Behavior-Based Scale to Assess Retail Salesperson Performance." Journal of Retailing 66 (Spring): 119-136.

Charnes, Abraham, William W. Cooper, Arie Y. Lewin, and Lawrence M. Seiford. 1994. Data Envelopment Analysis: Theory, Methodology and Applications. 
Edited by A. Charnes, William W. Cooper, Arie Y. Lewin, and Lawrence M. Seiford. Kluwer Academic Publishers.

Charnes, Abraham, William W. Cooper, and E. Rhodes. 1978. "Measuring the Efficiency of Decision Making Units." European Journal of Operational Research 2:429-444.

Donthu, Naveen, and Boonghee Yoo. 1998. "Retail Productivity Assessment Using Data Envelopment Analysis." Journal of Retailing 74 (1): 89-105 (Spring).

Farrell, M. J. 1957. "The Measurement of Productive Efficiency." Journal of the Royal Statistical Society. Series A (General) 120 (3): 253-290.

Färe, Rolf, and Shawna Grosskopf. 1985. "A Nonparametric Approach to Scale Efficiency." Scandinavian Journal of Economics 87:594-604.

Grewal, Dhruv, Michael Levy, Anuj Mehrotra, and Arun Sharma. 1999. "Planning Merchandising Decisions to Account for Regional and Product Assortment Differences." Journal of Retailing 75 (3): 405-424. ISSN: 0022-4359.

Gutierrez, R. G., S. L. Carter, and D. M. Drukker. 2001. sg 160: On boundaryvalue Log-likelihood Ratio Test. Stata Technical Bulletin 60, 15-18. Reprinted in Stata Technical Bulletin Reprints, 8, 233-236.

Kendall, Maurice G. 1955. Rank Correlation Methods. $2^{\text {nd }}$. London, United Kingdom: Charles Griffin \& Company.

Kmenta, Jan. 1990. Elements of Econometrics. 2nd. New York (NY), USA: Macmillan Publishing Company. page 491.

Kumbhakar, Subal C., and C. A. Knox Lovell. 2000. Stochastic Frontier Analysis.

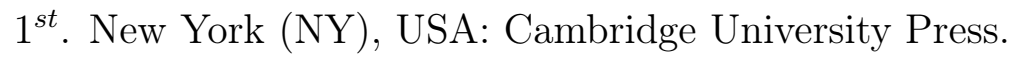

Löthgren, Mickael, and Magnus Tambour. 1996, (January). "Alternative Approaches to Estimate Returns to Scale in DEA-Models." Working paper series in economics and finance 90, Stockholm School of Economics - The Economic Research Institute.

Lusch, Robert F., and Ray R. Serpkenci. 1990. "Personal Differences, Job Tension, Job Outcomes and Store Performance: A Study of Retail Store Managers." Journal of Marketing 54 (January): 85-101.

Marschak, Jacob, and William H. Andrews. 1944. "Random Simultaneous Equations and the Theory of Production." Econometrica 12 (3/4): 143-205 (July).

MecKenzie, Scott B., Philip M. Podsakoff, and Richard Fetter. 1993. "The Impact of Organizational Citizenship Behavior on Evaluations of Salesperson Performance." Journal of Marketing 57 (January): 70-80.

Meeusen, W., and J. van den Broeck. 1977. "Efficiency Estimation from CobbDouglas Production Functions with Composed Error." International Economic Review 18 (June): 435-444.

Mehrotra, Sanjay. 1992. "On the Implementation of a Primal-Dual Interior Point Method." SIAM Journal on Optimization 2 (4): 575-601 (November). 
Mortimer, Duncan. 2002, (September). "Competing Methods for Efficiency Measurement: A Systematic Review of Direct DEA vs SFA/DFA Comparisons." Working Paper 136, Centre for Health Program Evaluation, Monash University, Victoria, Australia.

Parasuraman, A., Valarie A. Zeithaml, and Leonard L. Berry. 1994. "Alternative Scales for Measuring Service Quality: A Comparative Assessment Based on Psychometric and Diagnostic Criteria." Journal of Retailing 70:193-199.

Reynolds, Dennis. 2004. "An Exploratory Investigation of Multiunit Restaurant Productivity Assessment Using Data Envelopment Analysis." Journal of Travel and Tourism Marketing 16 (2/3): 19-26 (January).

Schmidt, Peter, and R. C. Sickles. 1984. "Production Frontiers and Panel Data." Journal of Business and Economic Statistics 2 (4): 367-374 (October).

Spearman, C. 1904. "The Proof and Measurement of Association between Two Things." American Journal of Psychology 15:72-101.

Stabell, Charles B., and Oystein D. Fjeldstadt. 1998. "Configuring Value of Competitive Advantage: On Chains, Shops and Networks." Strategic Management Journal 19 (5): 413-437 (May).

Stata Corporation. 2003. Stata 8.0 Reference Manual: N-Z. Release 8.0. College Station, Texas, USA: Stata Statistical Software.

Steering Committee for the Review of Commonwealth/State Service Provision. 1997. "Data Envelopment Analysis: A Technique for Measuring the Efficiency of Government Service Delivery." Discussion Paper, AGPS, Canberra, Australia. 0-646-33533-2.

Sueyoshi, Toshiyuki. 1997. "Measuring Efficiencies and Returns to Scale of Nippon Telegraph \& Telephone in Production and Cost Analyses." Management Science 43 (6): 779-797 (June).

Tone, Kaoru. 1993. "An Epsilon-Free DEA and a New Measure of Efficiency." Journal of the Operations Research Society of Japan 36 (3): 167-174.

Vellman, P.F., and R. Welsch. 1981. "Efficient Computing of Regression Diagnostics." The American Statistician 35:234-242.

Winsten, C. B. 1975. "Discussion of Mr. Farrell's Paper." Journal of the Royal Statistical Society. Series A (General) 120 (3): 282-284.

Zhu, Joe, and Zhao-Han Shen. 1995. "Theory and Methodology: A Discussion of Testing DMUs' Returns to Scale." European Journal of Operational Research 81 (3): 590-596. 


\section{A Figures and Tables}

\begin{tabular}{l||rrrrr}
\hline Variables & Obs. & Mean & STD. Dev. & Min & \multicolumn{1}{c}{ Max } \\
\hline \hline Inputs & & & & & \\
Size $\left(\mathrm{m}^{2}\right)$ & 42 & 38.95 & 28.43 & 5 & 122 \\
Employees & 42 & 17.73 & 4.10 & 3 & 27 \\
Outputs & & & & & \\
SIM cards sold & 42 & 2507.16 & 1428.56 & 793 & 6869 \\
Sold SIM cards revenue & 42 & 31.8033 & 19.6507 & 8.5255 & 92.6930 \\
\hline
\end{tabular}

Table 1: Input-output summary

Inputs-outputs relations
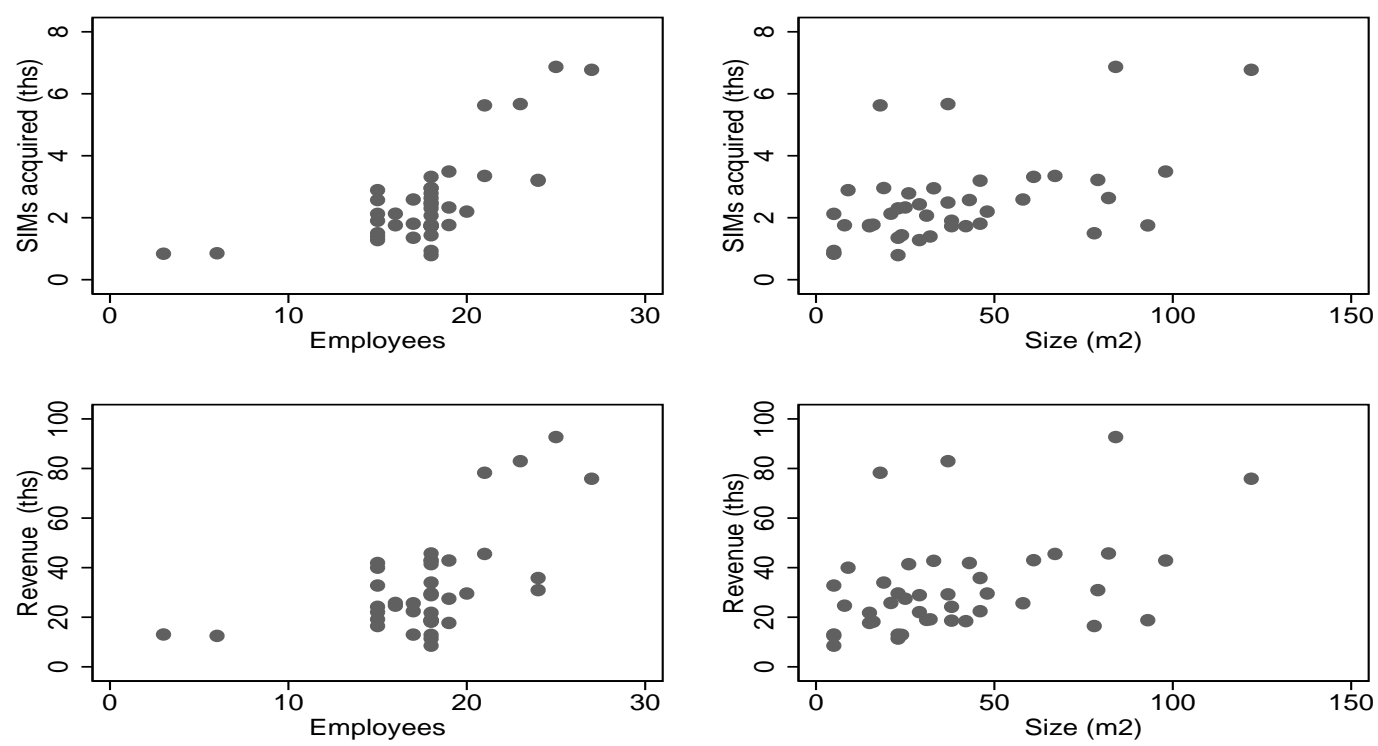

Figure 1: Inputs-outputs relations 


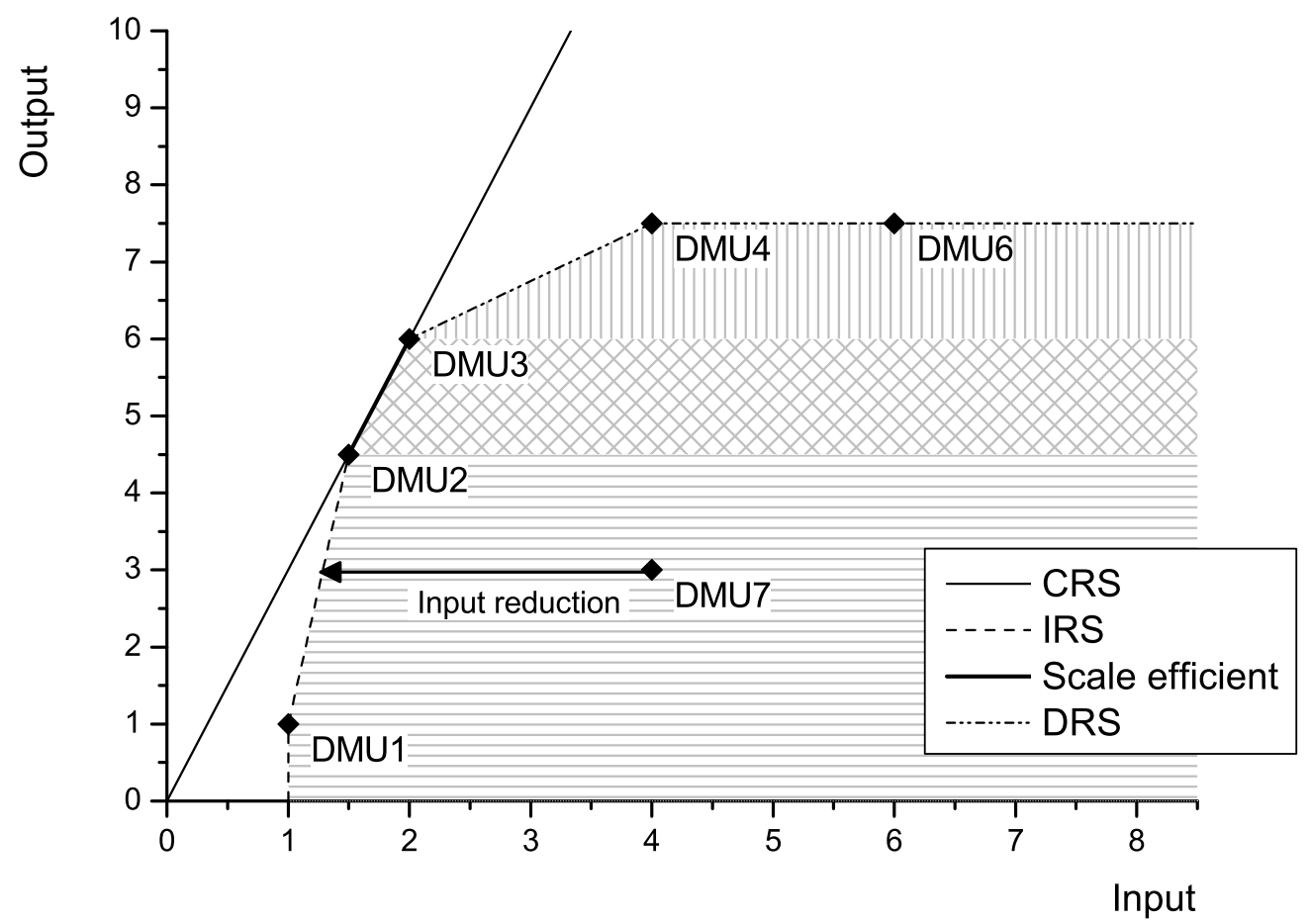

Figure 2: Production frontier and returns to scale types

\begin{tabular}{l||ll|ll}
\hline Rank & SIMs per m2 & SIMs per empl. & Revenue per m2 & Revenue per empl. \\
\hline \hline Top 4 & DMU39 & DMU33 & DMU39 & DMU33 \\
& DMU4 & DMU31 & DMU4 & DMU4 \\
& DMU6 & DMU4 & DMU6 & DMU31 \\
& DMU12 & DMU24 & DMU12 & DMU30 \\
\hline Middle 4 & DMU31 & DMU13 & DMU13 & DMU14 \\
& DMU22 & DMU29 & DMU5 & DMU17 \\
& DMU25 & DMU22 & DMU25 & DMU13 \\
& DMU9 & DMU17 & DMU22 & DMU12 \\
\hline Bottom 4 & DMU2 & DMU1 & DMU27 & DMU1 \\
& DMU32 & DMU37 & DMU29 & DMU37 \\
& DMU8 & DMU35 & DMU8 & DMU2 \\
& DMU15 & DMU2 & DMU15 & DMU35 \\
\hline \multicolumn{7}{|c|}{0.28} & & 0.47 \\
\hline
\end{tabular}

Table 2: Ratio scores ranking 


\begin{tabular}{|c|c|c|c|c|c|c|}
\hline \multicolumn{2}{|l|}{ Model } & Obs. & Mean & Std.Dev. & Min & Max \\
\hline \multirow[t]{5}{*}{$\overline{\overline{\text { SIMs }}}$} & $\chi-\mathrm{CCR}$ & $\overline{42}$ & .4474 & .2235 & .1510 & 1 \\
\hline & $\theta-\mathrm{CCR}$ & 42 & .5341 & .2196 & .1606 & 1 \\
\hline & $\chi-\mathrm{BCC}$ & 42 & .5394 & .2312 & .1962 & 1 \\
\hline & $\theta-\mathrm{BCC}$ & 42 & .5736 & .2380 & .2174 & 1 \\
\hline & Scale efficiency & 42 & .9433 & .1175 & .4372 & 1 \\
\hline \multicolumn{7}{|c|}{ Revenue } \\
\hline & $\chi^{-\mathrm{CCR}}$ & 42 & .3855 & 2410 & .1039 & 1 \\
\hline & $\theta-\mathrm{CCR}$ & 42 & .4555 & 2358 & .1560 & 1 \\
\hline & $\chi-\mathrm{BCC}$ & 42 & .4161 & .2976 & .0966 & 1 \\
\hline & $\theta-\mathrm{BCC}$ & 42 & .5253 & .2675 & .2049 & 1 \\
\hline & Scale efficiency & 42 & .8830 & .1261 & .2600 & 1 \\
\hline \multicolumn{4}{|c|}{ SIMs\&Revenue } & & & \\
\hline & $\chi^{-\mathrm{CCR}}$ & 42 & .3856 & 2410 & .1040 & 1 \\
\hline & $\theta-\mathrm{CCR}$ & 42 & .5377 & .2193 & .1606 & 1 \\
\hline & $\chi-\mathrm{BCC}$ & 42 & .4799 & .2728 & .1550 & 1 \\
\hline & $\theta-\mathrm{BCC}$ & 42 & .5841 & .2414 & .2174 & 1 \\
\hline & Scale efficiency & 42 & .9333 & 1152 & .4372 & 1 \\
\hline
\end{tabular}

Table 3: Efficiency scores $(\chi)$ and $\theta$ summary statistics

\begin{tabular}{ll||ll|ll|ll}
\hline \multicolumn{1}{l|}{ Model } & & \multicolumn{2}{|c|}{ SIMs } & \multicolumn{2}{|l|}{ Revenue } & \multicolumn{2}{|l}{ SIMs\&Revenue } \\
& & CCR & BCC & CCR & BCC & CCR & BCC \\
\hline \hline SIMs & CCR & 1.0000 & & & & & \\
& BCC & 0.8802 & 1.0000 & & & & \\
\hline Revenue & CCR & 0.9115 & 0.8436 & 1.0000 & & & \\
& BCC & 0.8815 & 0.7979 & 0.9092 & 1.0000 & & \\
\hline \multirow{2}{*}{ SIMs\&Revenue } & CCR & 0.9109 & 0.8439 & 0.9994 & 0.9089 & 1.0000 & \\
& BCC & 0.8457 & 0.9436 & 0.8350 & 0.8246 & 0.8353 & 1.0000 \\
\hline
\end{tabular}

Note: All coefficients are significantly different from 0 at $1 \%$ level.

Table 4: Spearman rank correlation 


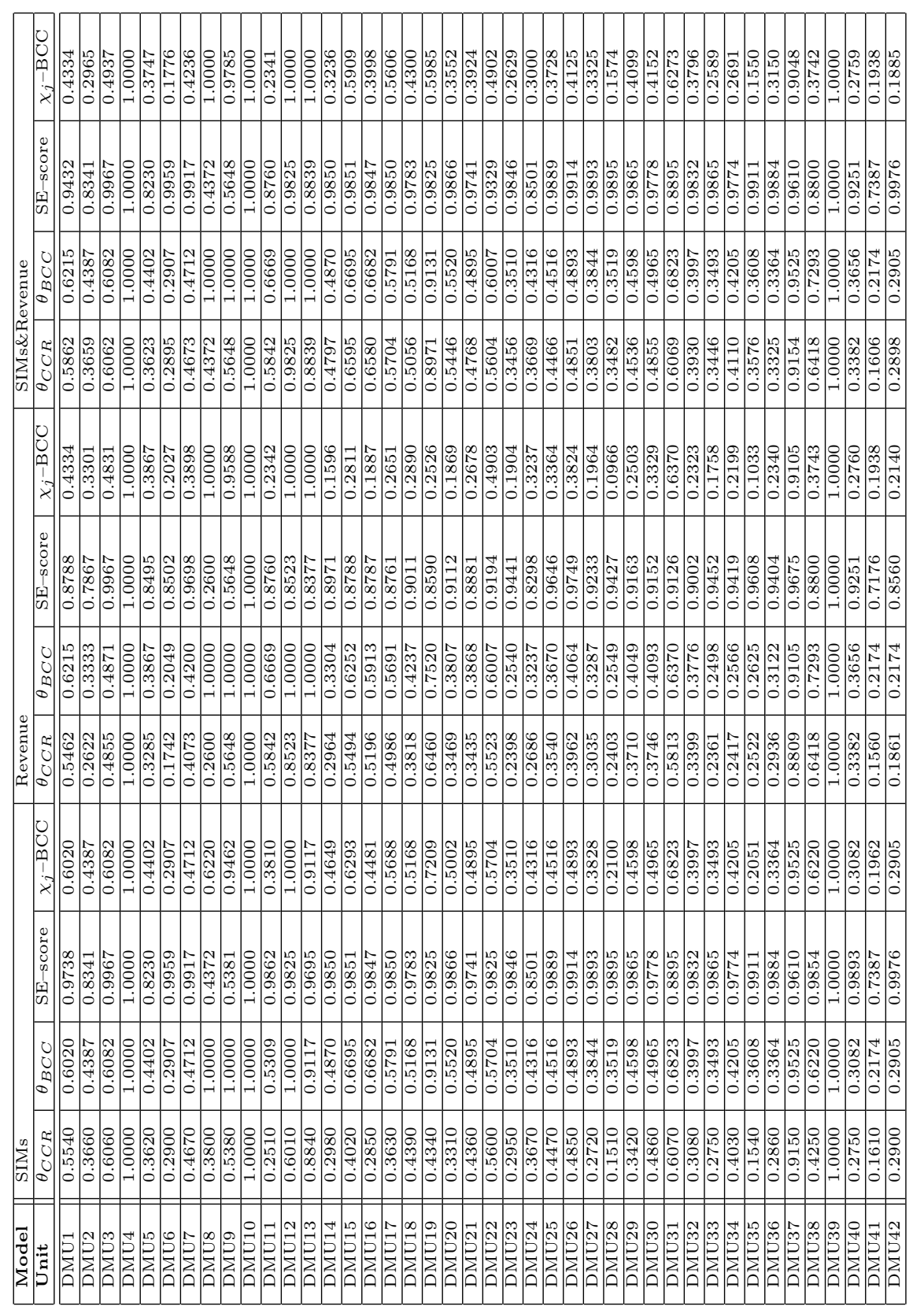




\begin{tabular}{l||ccccc}
\hline Relative slacks & Obs. & Mean & Std. Dev. & Min & Max \\
\hline \hline Employees - BCC & 42 & 0.0009 & 0.0060 & 0 & 0.0395 \\
Employees - CCR & 42 & 0.0017 & 0.0112 & 0 & 0.0727 \\
Size - BCC & 42 & 0.0626 & 0.1281 & 0 & 0.5280 \\
Size - CCR & 42 & 0.1114 & 0.1547 & 0 & 0.5663 \\
\hline
\end{tabular}

Table 6: Relative non-proportional slacks summary

\begin{tabular}{l||ccc}
\hline Model & IRS & $\begin{array}{c}\text { RTS type } \\
\text { Scale efficient }\end{array}$ & DRS \\
\hline \hline SIMs & 8 & 3 & 31 \\
\hline Revenue & 10 & 3 & 29 \\
\hline SIMs\&Revenue & 8 & 3 & 31 \\
\hline
\end{tabular}

Table 7: Returns to scale summary

\section{COLS-SIMs}

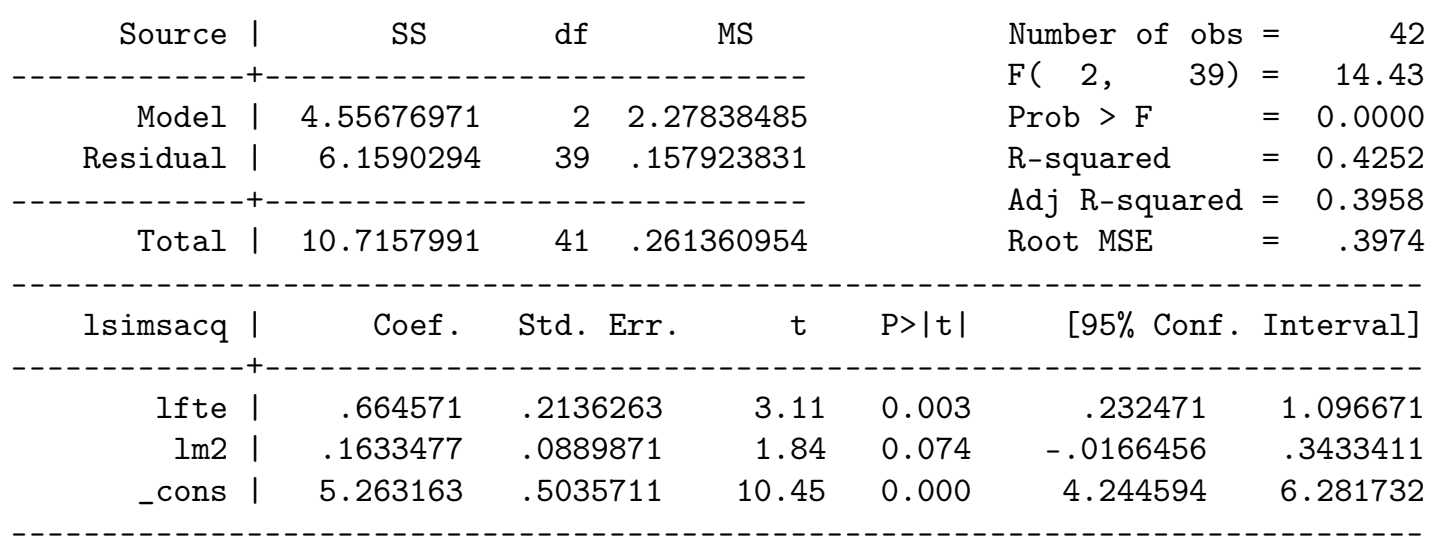

\section{COLS-revenue}

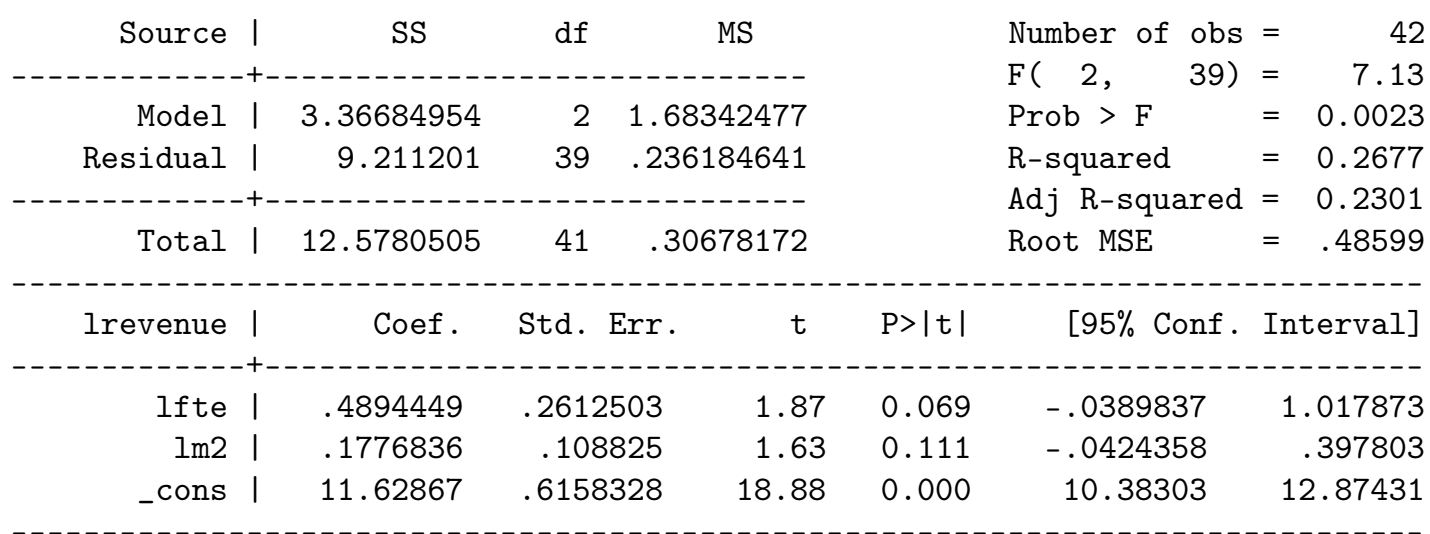

Table 8: COLS - results for full sample 


\section{SFA-SIMs}

\begin{tabular}{|c|c|c|c|c|c|c|}
\hline Stoc. frontier & $\mathrm{rmal} / \mathrm{ha}$ & rmal m & & $\begin{array}{l}\text { Numb } \\
\text { Wald }\end{array}$ & $\begin{array}{l}\text { of obs } \\
\text { hi2(2) }\end{array}$ & $\begin{array}{r}42 \\
31.07\end{array}$ \\
\hline Log likelihood & -19.28066 & & & Prob & $\operatorname{chi} 2$ & 0.0000 \\
\hline-----------1 & ------ & 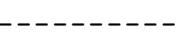 & & --- & ------------ & -------- \\
\hline Isimsacq | & Coef. & Std. Err. & $z$ & $\mathrm{P}>|z|$ & {$[95 \%$ Conf. } & Interval] \\
\hline---------+ & ------- & ---------- & ---- & ----- & ----------- & --------1 \\
\hline lfte | & .664576 & .2058572 & 3.23 & 0.001 & .2611033 & 1.068049 \\
\hline $\operatorname{lm} 2 \quad \mid$ & .1633458 & .0857516 & 1.90 & 0.057 & -.0047243 & .3314159 \\
\hline _cons I & 5.279347 & 1.060924 & 4.98 & 0.000 & 3.199975 & 7.358719 \\
\hline-------+ & --------- & --------- & & & ------1 & ------ \\
\hline sigma_v | & .382747 & .0476542 & & & .2998695 & .48853 \\
\hline sigma_u | & .0203664 & 1.184192 & & & $6.55 e-52$ & $6.33 e+47$ \\
\hline sigma2 | & .14691 & .0443624 & & & .0599613 & .2338587 \\
\hline lambda | & .053211 & 1.207792 & & & -2.314017 & 2.420439 \\
\hline
\end{tabular}

Likelihood-ratio test of sigma_u=0: $\operatorname{chibar2}(01)=0.00 \quad$ Prob $>=\operatorname{chibar} 2=1.000$

\section{SFA-revenue}

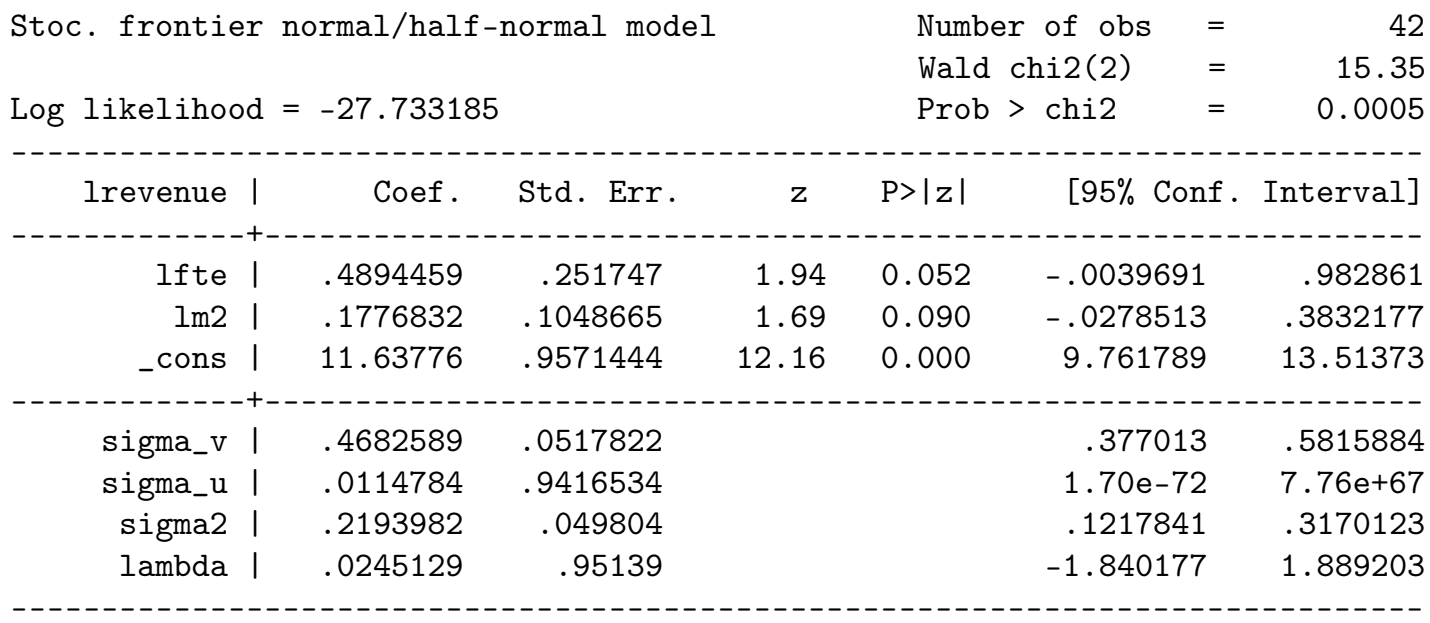

Likelihood-ratio test of sigma_u=0: $\operatorname{chibar2}(01)=0.00 \quad$ Prob $>=\operatorname{chibar} 2=1.000$

Table 9: SFA - results for full sample

\begin{tabular}{l||rrrrr}
\hline Model & Obs & Mean & Std. Dev. & Min & Max \\
\hline \hline COLS-SIMs & 42 & 0.4479 & 0.1807 & 0.1500 & 1.0000 \\
COLS-Revenue & 42 & 0.3960 & 0.1976 & 0.1474 & 1.0000 \\
SFA-SIMs & 42 & 0.9839 & 0.0003 & 0.9828 & 0.9848 \\
SFA-Revenue & 42 & 0.9909 & 0.0001 & 0.9907 & .9911 \\
\hline \hline
\end{tabular}

Table 10: Parametric methods: Technical efficiency summary 


\begin{tabular}{l||cccc}
\hline Ranking & COLS-SIMs & COLS-Rev. & DEA-Rev. VRS & DEA-SIMs VRS \\
\hline \hline COLS-SIMs & 1.0000 & & & \\
COLS-Revenue & 0.9316 & 1.0000 & & \\
DEA-Revenue VRS & 0.6018 & 0.6562 & 1.0000 & \\
DEA-SIMs VRS & 0.8550 & 0.8128 & 0.8071 & 1.0000 \\
\hline
\end{tabular}

Note: All coefficients are significantly different from 0 at $1 \%$.

Table 11: Spearman rank correlation coefficients COLS-DEA (42 obs.)

\begin{tabular}{l||ccc}
\hline Model & Sum of elasticities & $\mathrm{F}(1,39)$ & Prob > F \\
\hline COLS-SIMs & 0.8279 & 0.9300 & 0.3416 \\
COLS-Revenue & 0.6671 & 2.3200 & 0.1359 \\
\hline Model & Sum of elasticities & chi2(1) & Prob > chi2 \\
\hline SFA-SIMs & 0.8279 & 1.0000 & 0.3178 \\
SFA-Revenue & 0.6671 & 2.5000 & 0.1140 \\
\hline
\end{tabular}

Note: Reduced sample

Table 12: Wald test for hypothesis H0: CRS production function

Technical efficiency scores

Density estimates
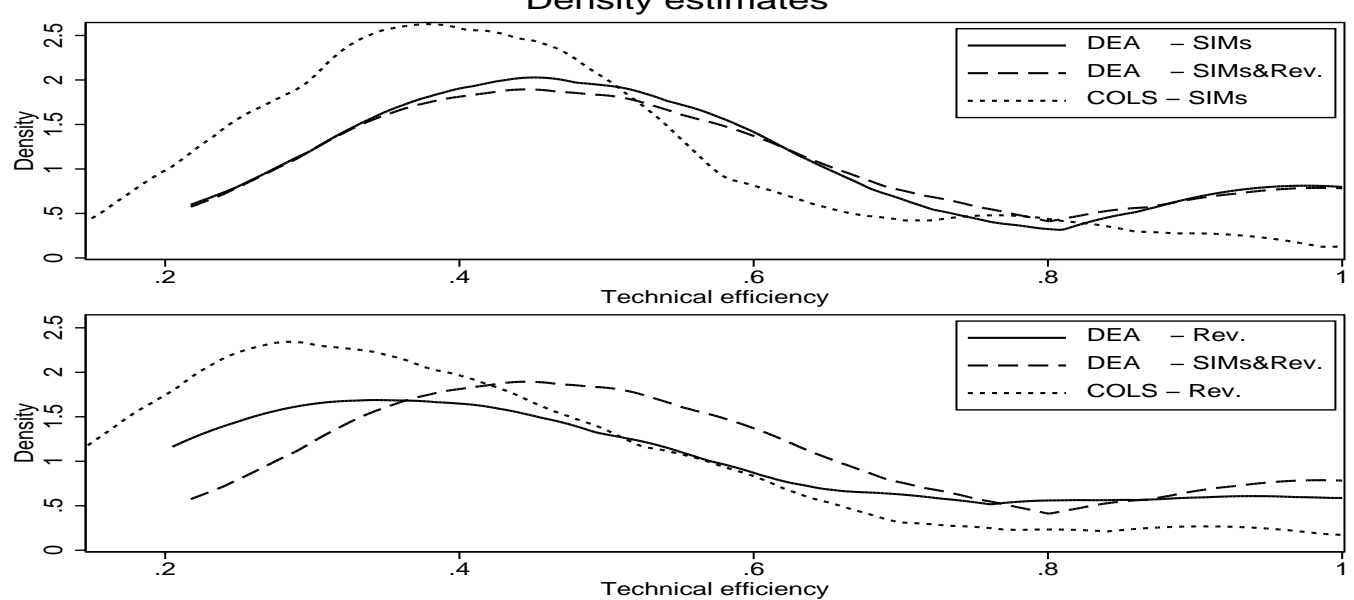

Figure 3: Comparison of density estimates (42 obs.) 


\section{COLS-SIMs}

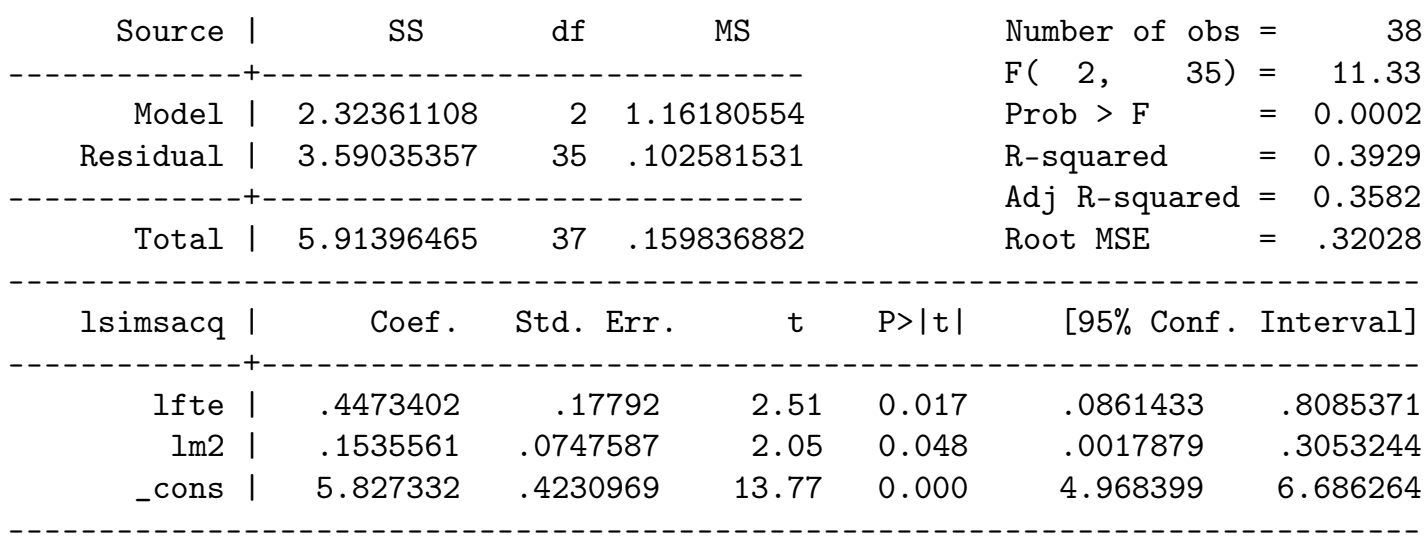

\section{COLS-revenue}

\begin{tabular}{|c|c|c|c|c|c|c|c|}
\hline Source I & SS & $d f$ & \multicolumn{2}{|r|}{ MS } & & Number of obs & $=\quad 38$ \\
\hline-------+ & ---------1 & & -- & ---- & & $F(2$, & 4.61 \\
\hline Model I & 1.49073594 & 2 & & 36797 & & Prob $>F$ & $=0.0167$ \\
\hline Residual | & 5.66231177 & 35 & .16 & 80336 & & R-squared & $=0.2084$ \\
\hline---------+- & ---------- & -- & --- & ---- & & Adj R-squared & $=0.1632$ \\
\hline Total I & 7.15304771 & 37 & .19 & 25614 & & Root MSE & .40222 \\
\hline Irevenue | & Coef. & Std. & Err. & $t$ & $P>|t|$ & {$[95 \%$ Conf. } & Interval] \\
\hline$\ldots$ & -------- & --- & -- & - & ----- & -- & ------- \\
\hline Ifte | & .2320428 & .22 & 436 & 1.04 & 0.306 & -.2215564 & .6856419 \\
\hline $\operatorname{lm} 2$ | & .1732971 & .0938 & 837 & 1.85 & 0.073 & -.0172969 & .363891 \\
\hline _cons I & 12.2748 & .531 & 346 & 23.10 & 0.000 & 11.19614 & 13.35347 \\
\hline
\end{tabular}

Table 13: COLS - results (38 obs.) 


\section{SFA-SIMs}

Stoc. frontier normal/half-normal model

Log likelihood $=-6.9128045$

Number of obs =

Wald $\operatorname{chi2}(2)=$

Prob > chi2 =
38

46.78

0.0000

\begin{tabular}{|c|c|c|c|c|c|c|}
\hline Isimsacq | & Coef & Std. Err. & z & $P>|z|$ & {$[95 \%$ Conf } & Interval] \\
\hline Ifte & 5718647 & 1427028 & 4.01 & 0.000 & 2921724 & .851557 \\
\hline $\operatorname{lm} 2 \mid$ & .0786142 & .0637068 & 1.23 & 0.217 & -.0462489 & .2034772 \\
\hline _cons I & 6.126882 & .2915422 & 21.02 & 0.000 & 5.55547 & 6.698295 \\
\hline & -- & $--7+7>$ & & & & -- \\
\hline sigma_v | & .094448 & .059624 & & & .0274055 & .3254973 \\
\hline sigma_u | & .4983721 & .0871752 & & & .3537216 & .7021759 \\
\hline sigma2 | & .2572952 & .0806131 & & & .0992963 & .415294 \\
\hline lambda | & 5.276685 & .1319612 & & & 5.018046 & 5.535325 \\
\hline
\end{tabular}

Likelihood-ratio test of sigma_u=0: $\operatorname{chibar2}(01)=4.36 \quad$ Prob $>=\operatorname{chibar} 2=0.018$

\section{SFA-revenue}

Stoc. frontier normal/half-normal model

Log likelihood $=-13.671618$

$\begin{array}{llr}\text { Number of obs } & = & 38 \\ \text { Wald chi2 }(2) & = & 7.850 e+08 \\ \text { Prob > chi2 } & = & 0.0000\end{array}$

$\begin{array}{llr}\text { Number of obs } & =38 \\ \text { Wald } \operatorname{chi}(2) & = & 7.850 \mathrm{e}+08\end{array}$

Prob > chi2 $=0.0000$

\begin{tabular}{|c|c|c|c|c|c|c|}
\hline Irevenue | & Coef & Std. Err. & z & $P>|z|$ & {$[95 \%$ Conf } & Interval] \\
\hline & & & & & & \\
\hline Ifte | & .3801373 & .0000816 & 4658.74 & 0.000 & .3799774 & .3802972 \\
\hline $\operatorname{lm} 2 \quad \mid$ & .0293778 & $6.84 e-06$ & 4294.70 & 0.000 & .0293644 & .0293912 \\
\hline _cons I & 12.90372 & .000208 & & 0.000 & 12.90331 & 12.90413 \\
\hline---+ & & -- & & & & --1 \\
\hline sigma_v | & $9.10 e-09$ & $2.37 e-06$ & & & $7.6 e-231$ & 1. $1 e+214$ \\
\hline sigma_u | & .6934945 & .0795493 & & & .5538645 & .8683255 \\
\hline sigma2 | & .4809346 & .110334 & & & .264684 & .6971853 \\
\hline lambda | & $7.62 \mathrm{e}+07$ & .0795493 & & & $7.62 e+07$ & $7.62 e+07$ \\
\hline
\end{tabular}

Likelihood-ratio test of sigma_u=0: $\operatorname{chibar2}(01)=8.15 \quad$ Prob $>=\operatorname{chibar} 2=0.002$

Table 14: SFA - results (38 obs.)

\begin{tabular}{l||rrrrr}
\hline Model & Obs & Mean & Std. Dev. & Min & Max \\
\hline \hline DEA-SIMs & 38 & 0.6800 & 0.2369 & 0.2174 & 1.0000 \\
DEA-Revenue & 38 & 0.5921 & 0.2825 & 0.2083 & 1.0000 \\
DEA-SIMs\&Rev. & 38 & 0.6986 & 0.2485 & 0.2174 & 1.0000 \\
COLS-SIMs & 38 & 0.5777 & 0.1666 & 0.2189 & 1.0000 \\
COLS-Revenue & 38 & 0.5263 & 0.1985 & 0.2262 & 0.9999 \\
SFA-SIMs & 38 & 0.6979 & 0.1767 & 0.2727 & 0.9578 \\
SFA-Revenue & 38 & 0.6110 & 0.2293 & 0.2023 & 0.9999 \\
\hline
\end{tabular}

Table 15: Parametric methods: Technical efficiency summary 


\begin{tabular}{l||ccc}
\hline Model & Sum of elasticities & $\mathrm{F}(1,35)$ & Prob > F \\
\hline COLS-SIMs & 0.6008 & 6.9500 & 0.0124 \\
COLS-Revenue & 0.4053 & 9.7800 & 0.0035 \\
\hline Model & Sum of elasticities & chi2 $2(1)$ & Prob > chi2 \\
\hline SFA-SIMs & 0.6504 & 10.3100 & 0.0013 \\
SFA-Revenue & 0.4095 & $6.2 \mathrm{e}+07$ & 0.0000 \\
\hline
\end{tabular}

Table 16: Wald test for hypothesis H0: CRS production function (38 obs.) 

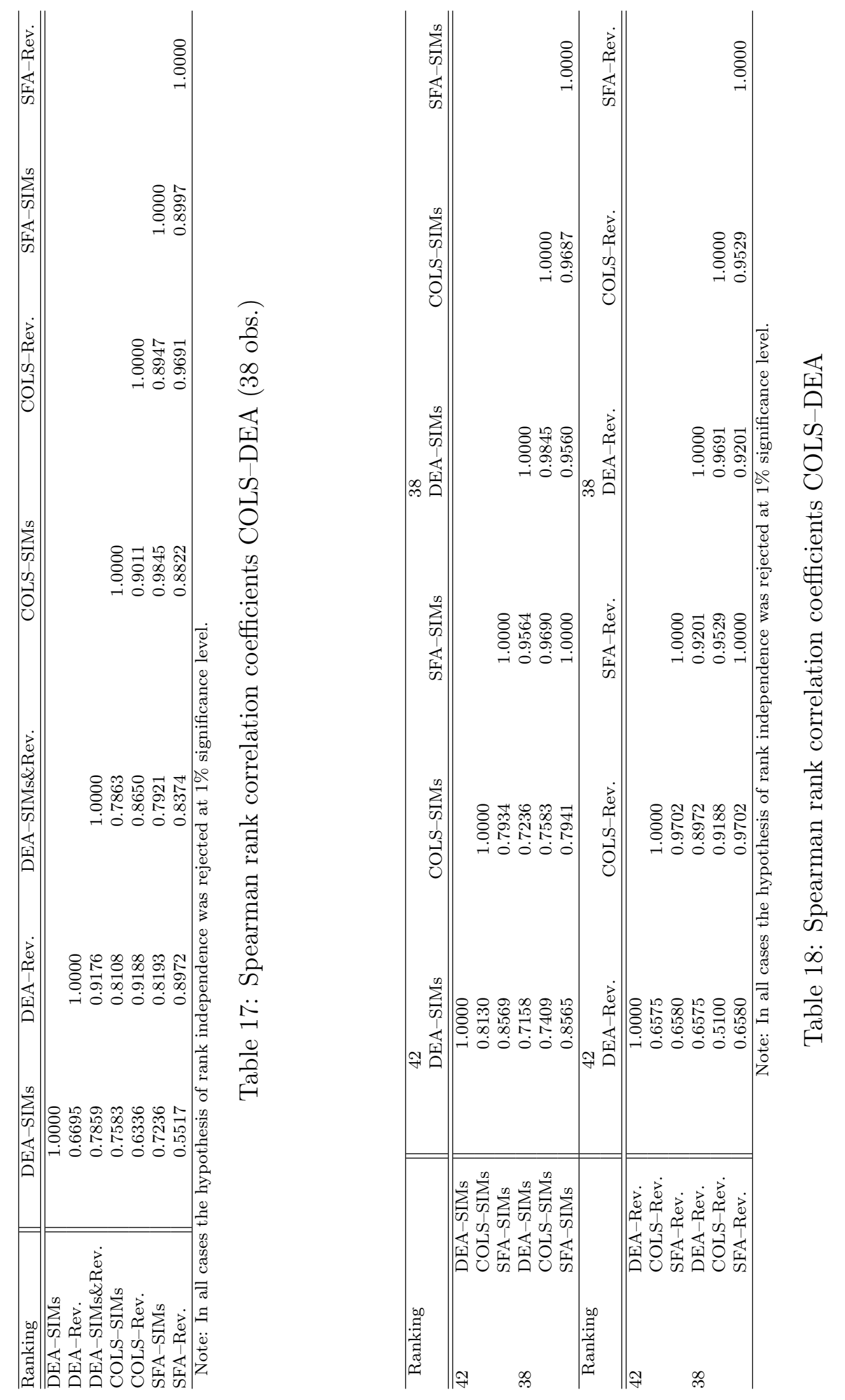


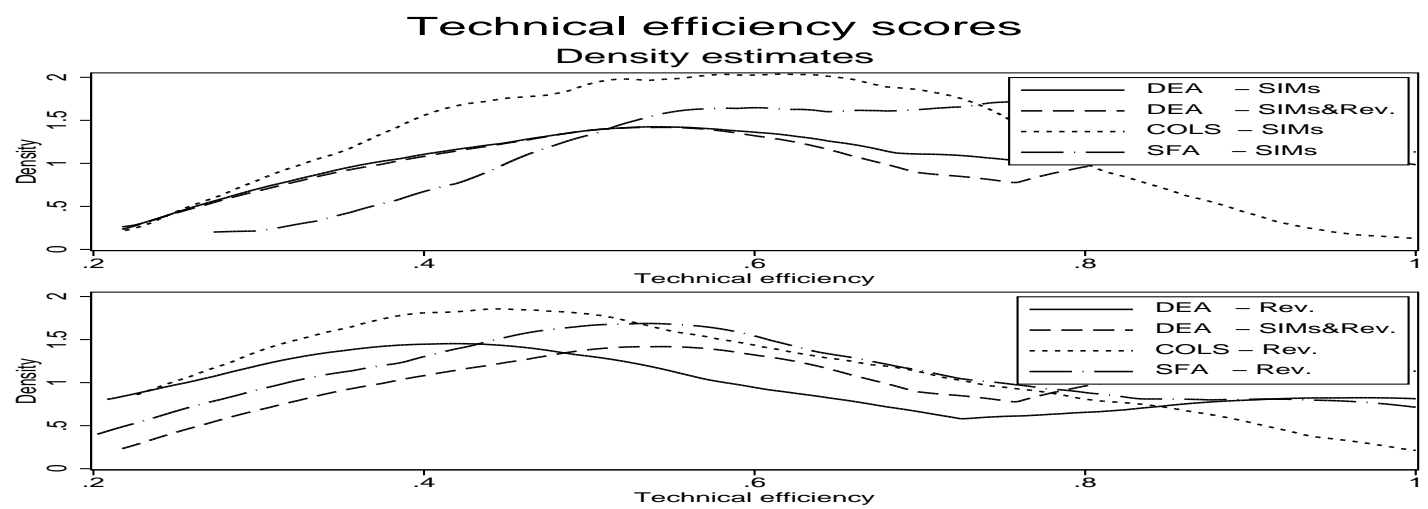

Figure 4: Comparison of density estimates (38 obs.)

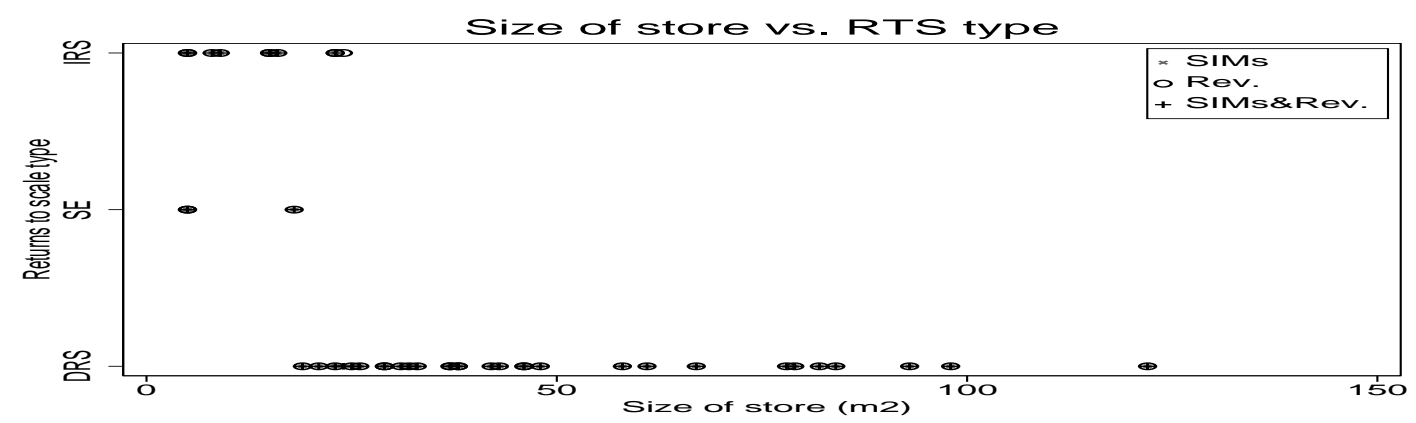

Figure 5: Returns to scale type and size of store

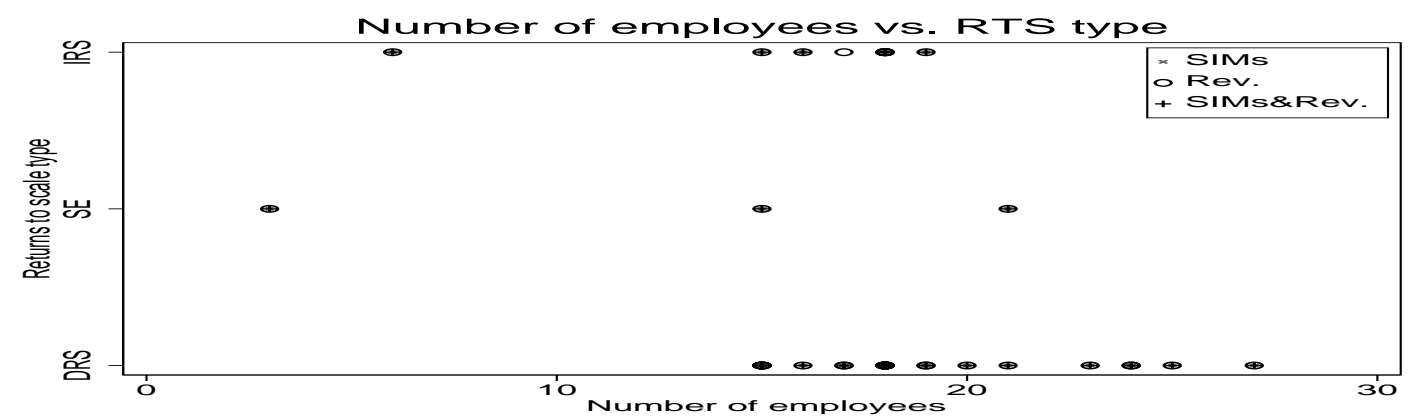

Figure 6: Returns to scale type and number of employees 
Store size vs. efficiency score

CCR--models

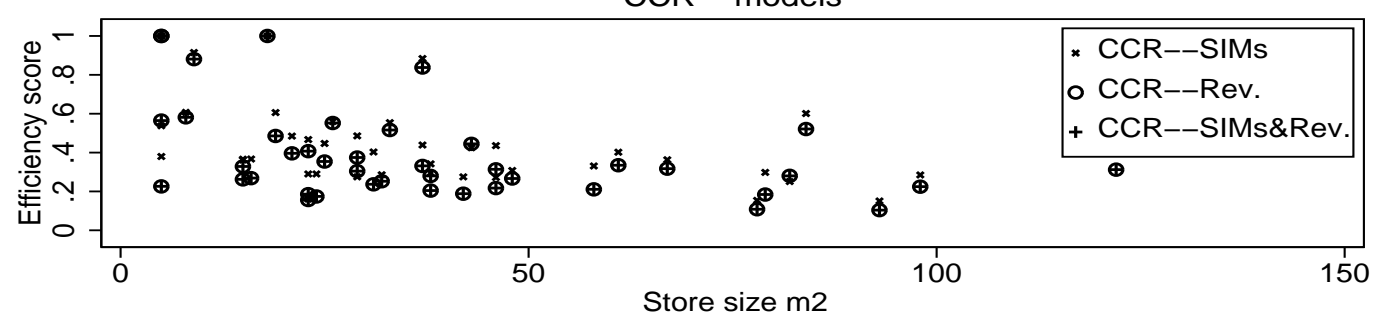

Store size vs. efficiency score

BCC--models

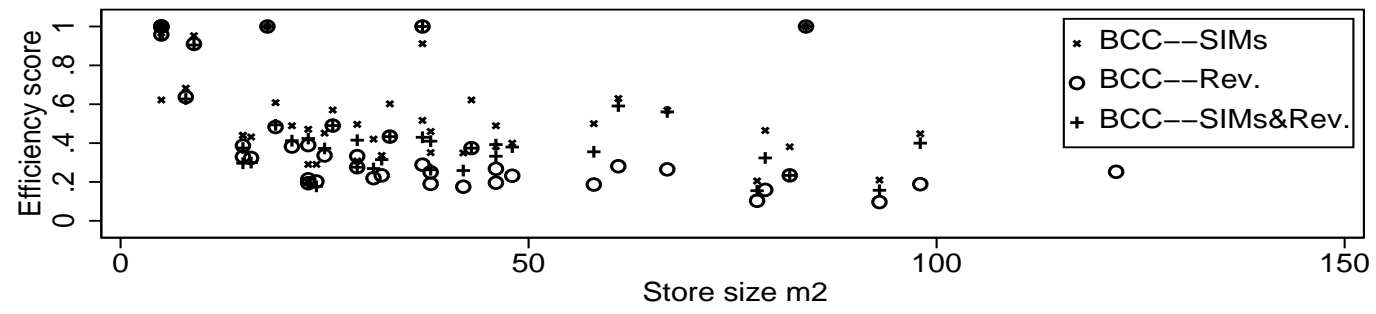

Figure 7: Size of store and efficiency score

Number of employees vs. efficiency score

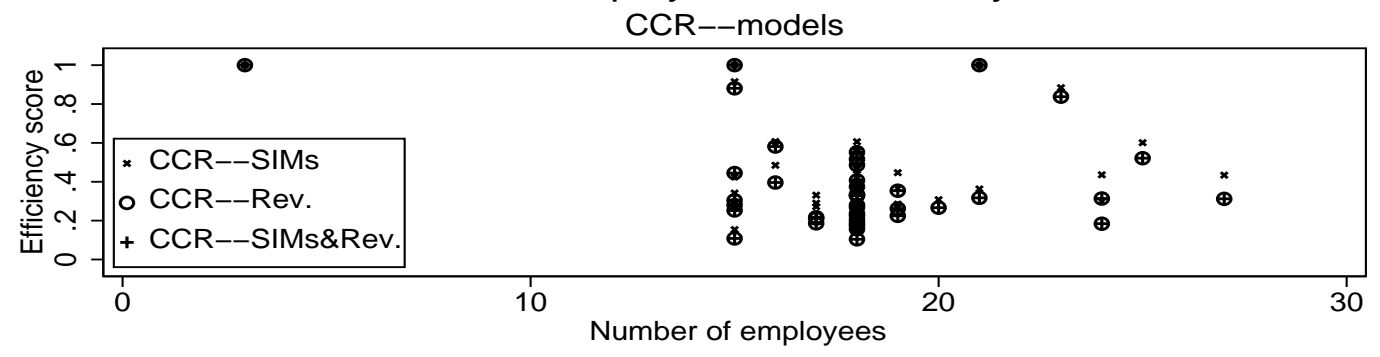

Number of employees vs. efficiency score

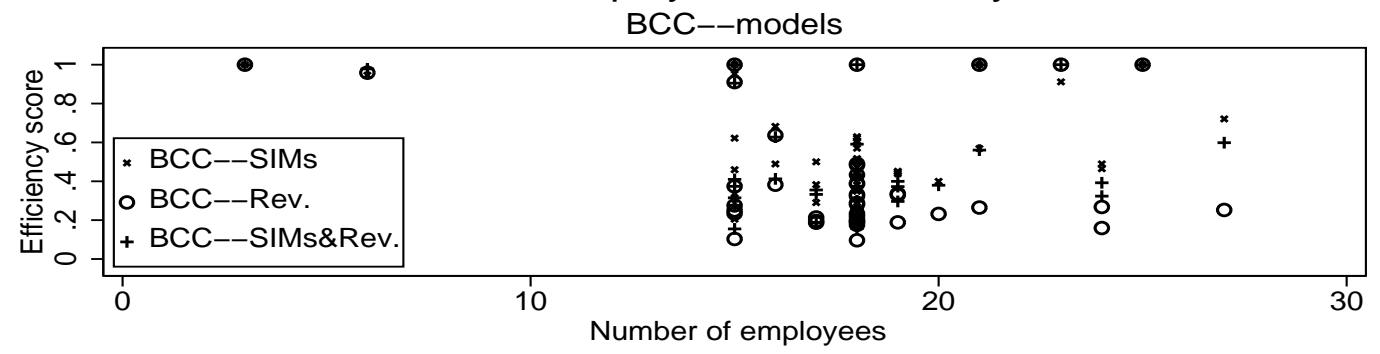

Figure 8: Number of employees and efficiency score 
DEA efficiency and SIMs sold performance

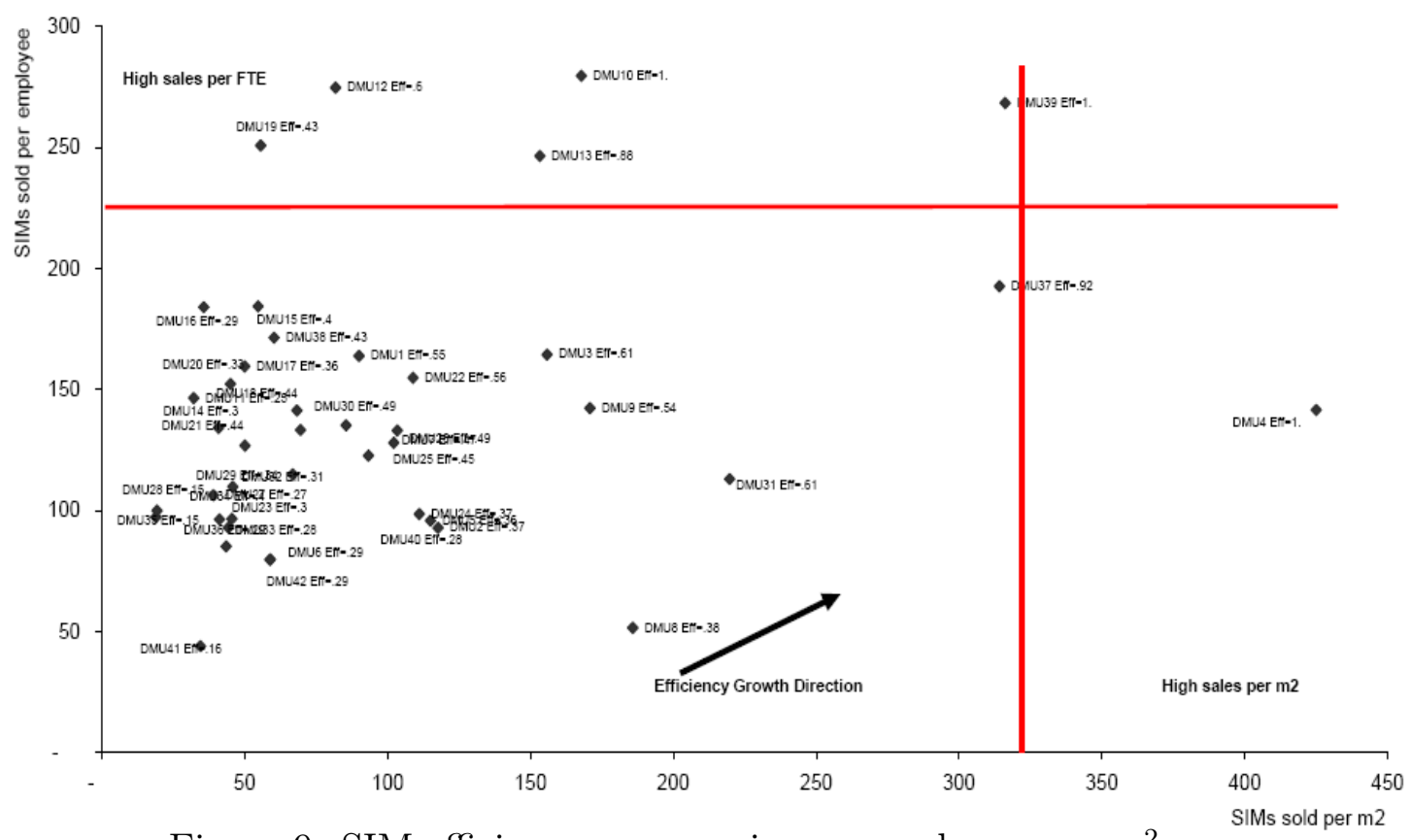

Figure 9: SIM efficiency measure in per employee-per $\mathrm{m}^{2}$ space

DEA Efficiency and revenue performance

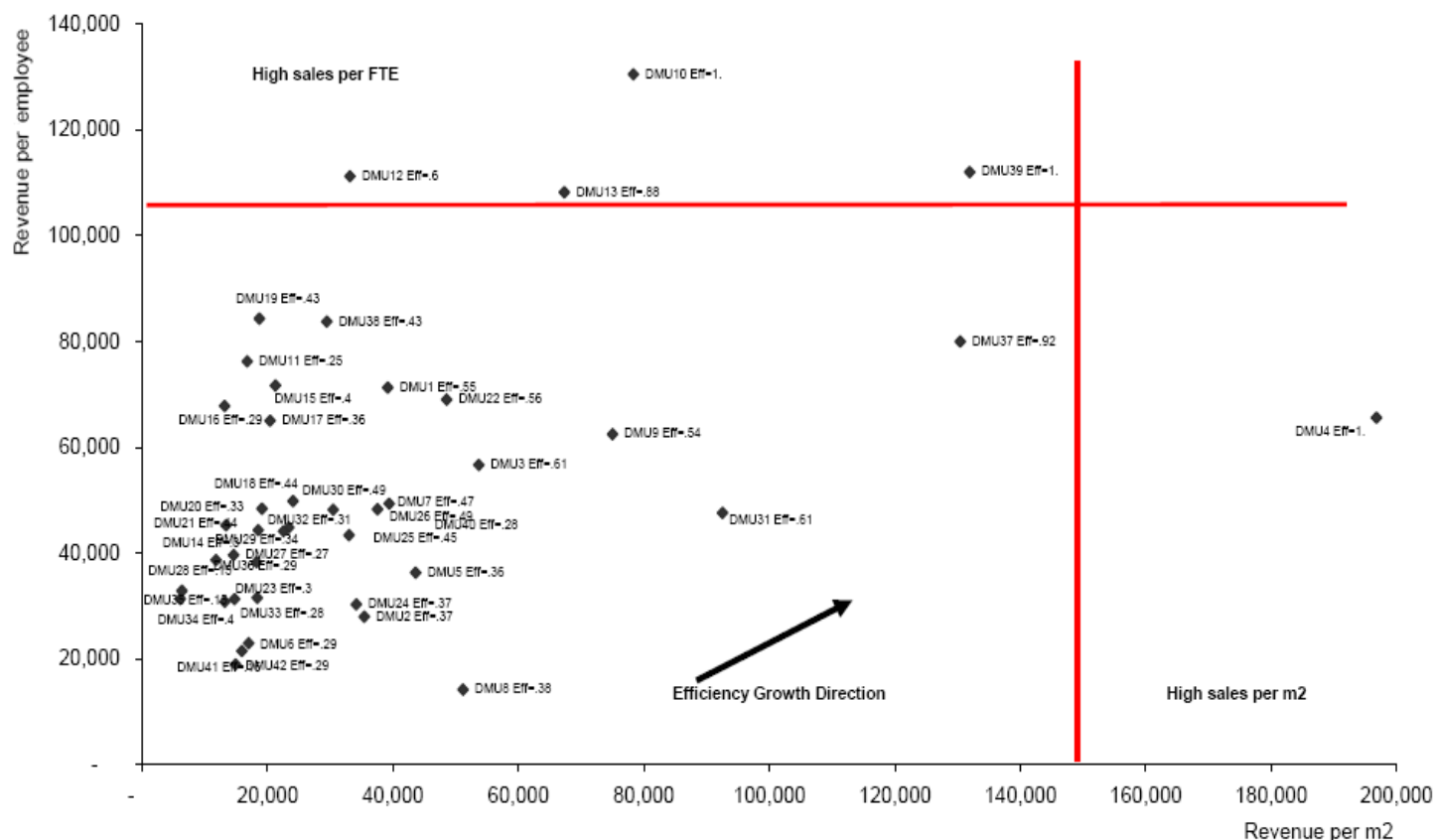

Figure 10: Revenue efficiency measure in per employee-per $\mathrm{m}^{2} \stackrel{\text { Revenue }}{\text { space }}$ 


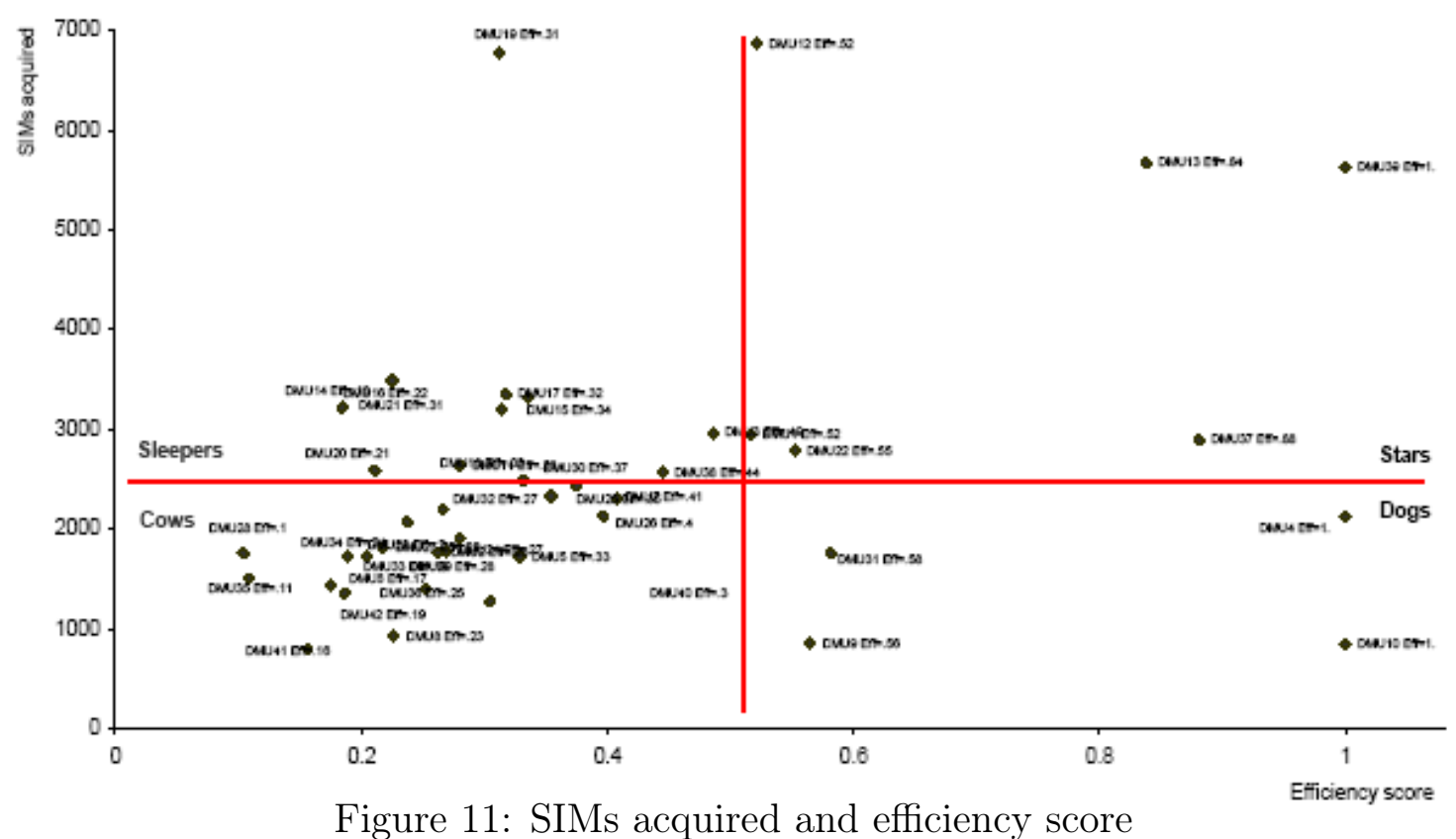

DEA elficiency and Revenue

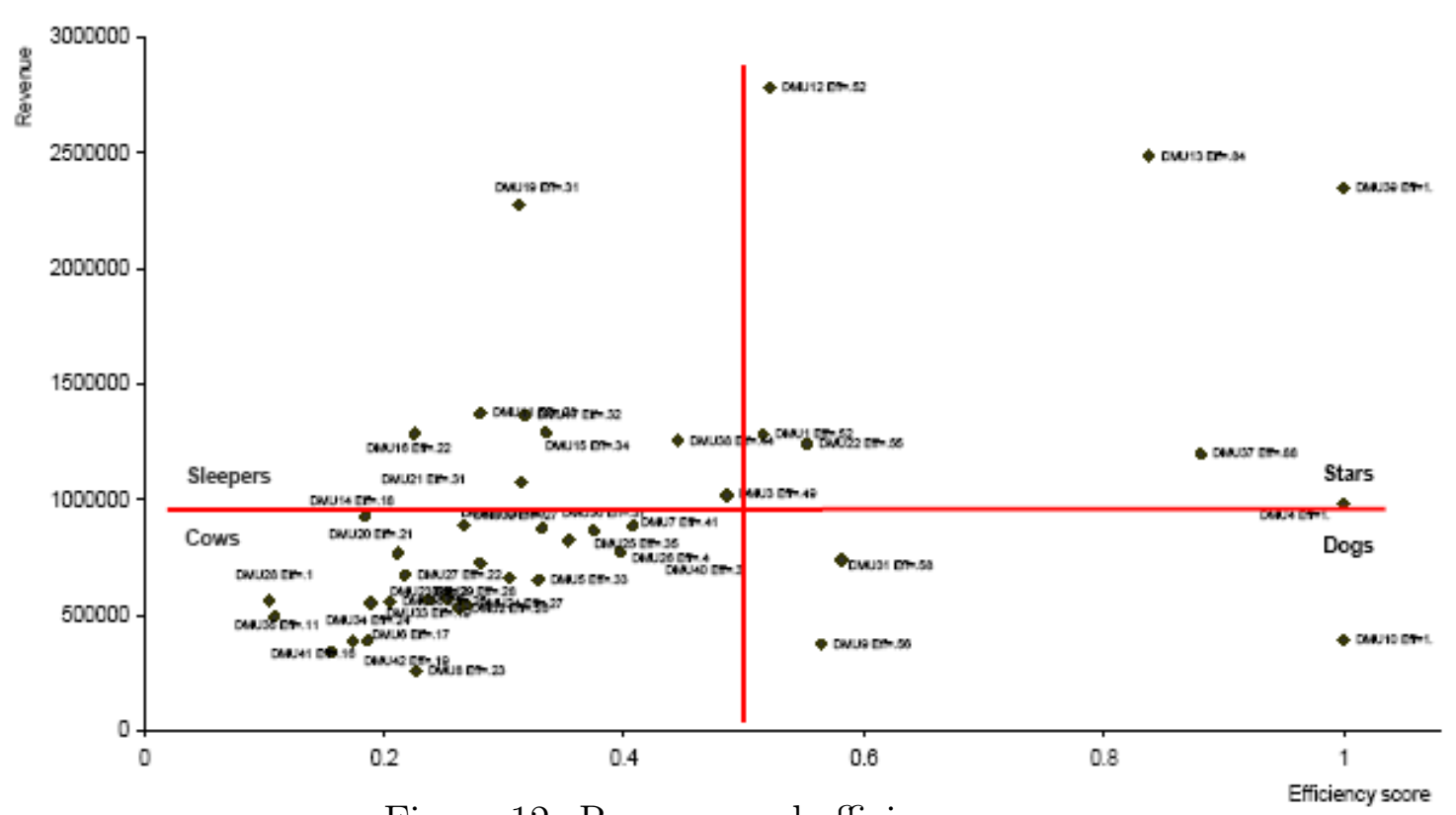

Figure 12: Revenue and efficiency score 
Individual researchers, as well as the on-line and printed versions of the CERGE-EI Working Papers (including their dissemination) were supported from the following institutional grants:

- Center of Advanced Political Economy Research [Centrum pro pokročilá politicko-ekonomická studia], No. LC542, (2005-2009),

- Economic Aspects of EU and EMU Entry [Ekonomické aspekty vstupu do Evropské unie a Evropské měnové unie], No. AVOZ70850503, (2005-2010);

- Economic Impact of European Integration on the Czech Republic [Ekonomické dopady evropské integrace na ČR], No. MSM0021620846, (2005-2011);

Specific research support and/or other grants the researchers/publications benefited from are acknowledged at the beginning of the Paper.

(c) František Brázdik, Viliam Druska, 2005

All rights reserved. No part of this publication may be reproduced, stored in a retrieval system or transmitted in any form or by any means, electronic, mechanical or photocopying, recording, or otherwise without the prior permission of the publisher.

Published by

Charles University in Prague, Center for Economic Research and Graduate Education (CERGE) and

Economics Institute (EI), Academy of Sciences of the Czech Republic

CERGE-El, Politických vězňu 7, 11121 Prague 1, tel.: +420 224005 153, Czech Republic.

Printed by CERGE-EI, Prague

Subscription: CERGE-El homepage: http://www.cerge-ei.cz

Editors: Directors of CERGE and EI

Managing editors: Deputy Directors for Research of CERGE and EI

ISSN 1211-3298

ISBN 80-7343-065-7 (Univerzita Karlova v Praze, CERGE)

ISBN 80-7344-054-7 (Národohospodářský ústav AV ČR, Praha) 
CERGE-EI

P.O.BOX 882

Politických vězňů 7

11121 Praha 1

Czech Republic http://www.cerge-ei.cz 